\title{
E-Government Developments
}

\section{Six Major Mechanisms of E-Government}

In an ecosystem, there are several factors that affect the health and richness of the system. For example, sufficient rainfall provides a water source for the survival of species and finally the water evaporates into the sky and completes the cycle. The implementation of e-Government can be illustrated as an ecosystem. There are six main mechanisms in an e-Government ecosystem: ICT preparedness, ICT usage, Enterprise Architecture (EA), ICT Model, Information provision capability, policy marketing, and resource allocation.

ICT preparedness is analogous to the environment, which is the availability of ICT. ICT usage is analogous to users of resources which is how the public sector uses available ICT technologies. EA ICT model acts as the physical rules of nature, which is the method and rule ensuring that ICT runs efficiently. Information provision capability resembles the visibility of the beauty of the environment, which is the availability and richness of content provided by the government to the public through ICT. Policy marketing resembles the measures promoting the environment, which is how the government promotes e-Government to the public. And finally, a resource allocation mechanism acts as a CIO that governs the overall measures of the e-Government implementation process. In the following section, detailed explanation of the major six mechanisms of eGovernment is presented.

Firstly, ICT preparedness refers to measuring stakeholders' ability for leveraging ICT and related applications. The stakeholders cover not only the government itself but also citizens and businesses. Secondly, ICT usage in the public sector focuses on how to measure government's ability on using ICT and related applications. Thirdly, the EA ICT model refers to the enterprise architecture model. According to Japan's Ministry of Economy, Trade and Industry (METI) definition, EA is a methodology for standardizing service procedures and information system, and creating highly efficient organization through optimizing the organization. It is also the basic principle for actualizing the highly efficient management of organizations. It can be seen as a way to get the internal effectiveness and efficiency of governmental operations. Fourthly, the information provision capability stresses the importance of the transparency and richness of information of e-Government. This is essential in order to involve citizens in the process of decision making. The quality and quantity of information provision are critical for a government on e-governance. Fifthly, policy marketing would be one of the main purposes of e-Government. Policy promotion through ICT increases the efficiency and transparency of government services, which in turn, reduce the transaction cost between the government and its stakeholders. Finally, government resource allocation is essential to sustain the e-Government mechanism. Government CIOs might be good candidates for making effective decisions on allocating limited resources. CIOs are expected to integrate management strategy with IT investment in order to balance the business strategy, organizational reform, and management reform.

With the major six mechanisms of e-Government, eco-system of e-Government can be established, and benefits of e-Government can be realized through this eco-system cycle.

\section{The E-Government Evolution}

The Waseda e-Government Rankings have been conducted for the past five years. During the last period, changes have been made to improve the quantity and quality of the ranking system. This year the past results were reviewed and most of measurements used in the research were revised. As a result, a new perspective for the development of e-Government or e-Governance can be added.

E-Government rankings are based on a principle of executing a comprehensive and systematical survey. Under this principle, the improvements have been made annually. In the first year, 2005, 23 countries are ranked with only 4 dimensions. In 2006, 9 other countries and 2 indicators which are management optimization and promotion of e-Government were added. In the third survey, Fiji and India were included for the first time. 
Although there are 6 indicators today, the title, definitions and contents of indicators has been redefined. The significant modification in the evaluation methodology is the replaces the previously used 5-point scales by check-lists which provides a higher degree of differentiation among surveyed countries, in 2008. For instance, corresponding to the definition the first subindicator 'Introduction to CIO' of 2007, in 2008 we detailed the 'Introduction to CIO or CIO presence' by 5 items and each item gets one point mark. Hence, it is easier for researchers to evaluate.

From 2007, according to trends and major issues occurred during the investigating year we started to give a subject for the e-Government ranking. For the previous two years, the subjects were the new role of $\mathrm{CIO}$ and online services application and e-Participation on the rise respectively.

Despite some substantial alterations made in the previous surveys to increase reliability of the ranking, there are still some limitations and obstacles to be addressed in succeeding surveys. Moreover, e-Government is still in the emerging stages. Hence, to meet these challenges the ranking process will continue to evolve.

\section{Obstacles and Limitations}

In spite of some significant modifications made in the current survey for increasing its reliability, it continues to have some limitations that should be addressed in the next survey.

As e-Government evolves, many countries are catching up with the leaders in offering more diverse, advanced and comprehensive electronic services through one-stop-shop portals. With the growing uniformity of offered services among the countries, the methodology applied in the survey is not anymore suitable for differentiation of the countries. One way to overcome this difficulty is to consider inclusion of additional services for evaluation. E-Healthcare and e-Education services might be considered as they serve as major indicators of the quality of life.

Another way is to look at the prospect of eParticipation and e-Democracy to be included as a result of the availability of new technology. Some countries are beginning to take advantages of Web 2.0 for establishing the interaction with their stakeholders and involving them into decision-making through online polls, surveys, blogs etc. Strong demand from the side of the citizens and other stakeholders to be fully integrated into the social and political life of their com- munities will foster new interaction modes between government and citizens. Strengthening of democratic processes by ICT in countries brings to the forefront the importance of electronic municipal services. The efforts to decentralize e-Government strategies can be clearly viewed in countries with strong democratic cultures, especially in Scandinavia where municipalities enjoy considerable independence. Provision of municipal services online is even more important as it helps bridge the digital divide among rural and central areas, which is of vital importance for the developing world. The shift from administrative to social and political services and as a consequence the shift from federal to local e-Government should be included in the next survey to produce effective differentiation between the countries.

\section{The Birth of E-Government Pillars}

The six pillars of e-Government, namely Network Preparedness, Required Interface - Functioning Applications, Management Optimization, National Portals, CIOs in Government and e-Government Promotion are based on earlier surveys, although significant changes and additions have been made to how each pillar is defined and measured in the current survey. These changes are intended to improve upon the previous methodologies.

The fundamental shift in the evaluation methodology comes from the introduction of checklists to replace the previously used 5-point scales which over time have resulted in minimal differentiation in more recent surveys. The checklists or the parameters that constitute each pillar have been formulated in a binary 'yes-no' manner so the evaluation remains independent of subjective interpretations of researchers. In earlier 5-point scale, the particular model definitions of scenarios for a country had to be mapped to an integral score (between 1 and 5) which meant only a certain number of permutations could be reflected in the 5 (or fewer) definitions. This meant the situation in a particular country could only be approximated by the closest model scenario implying a loss of granularity in the rankings. Now, the instrument provides a higher degree of differentiation. The pillars are composed of factors and the factors themselves are composed of (mostly) binary parameters. The number of factors has been increased from 21 (for all pillars) to 25 . It is important to clarify that 4 factors have not simply been added, rather many of the previous 21 have also been significantly restruc- 
tured or redefined. To observe the increased granularity, it should be noted that these 25 factors are now composed of as many as 138 parameters. Apart from the secondary data and expertise, e-Mail based cross checking of data was also used in this survey. Those responsible for publishing data used or those working in relevant organizations were contacted to establish or verify data.

In future surveys, evaluation methodology will be fine-tuned further at a parameter or even factor level. This may even expanded be to accommodate new services or trends. However, it is clear the fundamental framework for evaluating e-Governance is fairly robust and is likely to be used as a basis for future ranking projects.

\section{Management Optimization}

\section{Trends and Developments}

In past years, governments realized that Information and Communication Technologies (ICT) were able to help them streamline processes and optimize the productivity of their ministries and departments. However, not all governments emphasized such an integrated and uniformed effort. This situation can be found following the first edition of the ranking. For instance, the EGovernment Ranking in 2005 stated "Not only homepage appearances, presentations and web designs, but also linkage with the administrative ERP, enterprise resource planning, high leveled applications which may fulfill optimization for governments is becoming more and more important. Concerning the introduction of such applications, a gap between the advanced countries and the other countries can be found."

These findings were confirmed the next year, as it can be seen from the 2006 E-Government Ranking: "It is important for e-Government programs to optimize the whole administrative works using high-level applications, systematically and effectively. Under this consideration, EA.ICT investment, System optimization, Integrated network system are promoted mainly by the advanced countries while the countries which are ranked low in the research also progress with Administrative and budgetary systems, and Public management reform by ICT as well. Therefore, it can be said that, at this point in time, the difference in terms of e-Government established by advanced and some developing countries continue to be ambiguous".

The jurisdictions that scored highest in the "Optimization" category were: (1) United States of Amer- ica; (2) Singapore; (3) Japan; (4) Korea; (5) Taiwan; (6) Australia; (7) United Kingdom; (8) Malaysia; (9) Thailand; (10) Norway.

The use of ICT for improving internal processes is highlighted in the 2007 E-Government Ranking: "Many government organizations make a great effort with their e-Government implementation by getting caught up with how to manage their day-to-day operations and at the same time improve their internal processes. To systematically and effectively implement the practical objectives of e-Government to an entire bureaucracy, it is required for government services to be available to all stakeholders and to for immediate access providing continuous gains. For the past few years, evidences of optimized management and implementation of e-Government initiatives have been observed mostly from countries like Singapore, United States, France, Japan and Korea as they continue to rise in the rankings with more electronic transactions and processes now made available for the citizens".

The 2007 e-Government Ranking found many jurisdictions share the same relative stage of e-Government development, meaning that similar efforts are underway in this field: (1) Singapore; (2) United States of America; (2) France; (2) Japan; (2) Korea; (2) Sweden; (7) Malaysia; (8)Germany; (8)Hong Kong; (8) Taiwan; and (9) Thailand.

Finally, the 2008 e-Government Ranking showed a change in the countries that used to be leaders in this category for previous years:

"A growing number of government organizations have realized the need to continuously review and revise their internal processes so as to capitalize on the advantages of ICT while at the same time deliver quality services to all stakeholders. Competition has been fierce this year and many countries have made vast improvement in their effort of optimizing management within their government and these have been reflected in the results for the Management Optimization indicator."

Half of the jurisdictions that were in the top 10 for this indicator last year dropped out from the list. Norway, Canada, Finland, United Kingdom, New Zealand and Italy have replaced France, Japan, Malaysia, Germany, Taiwan and Thailand as among the top 10 countries/economies for this indicator. Among them, Norway has leapfrogged the countries into the top with its e-Norway 2009 plan slowly but surely bearing fruit since its inception in 2005.

Singapore, Hong Kong, USA, Korea and Sweden have maintained their stride and continue to build on 
what they have achieved in the past year. Newcomers to this e-Government ranking, for example, India is ranked in the middle group. As a new economic power for the 21 st century, Indian government's effort in optimizing and integrating its public sector will be closely monitored".

\section{Methodology}

In order to better quantify the efforts put in by governments, it was necessary to dissect these government initiatives. To ensure that all the efforts by these governments were properly measured, a detailed list of indicators was derived from the previous years. Thus in this newly revised indicator list, government's computerization efforts and the level of ICT integration attainment were measured

In the end, it was possible to quantify the government's efforts in these areas. Using the Capability Maturity Model as a reference, we could grade each government based on the level of maturity of their ICT integration.

$$
\begin{array}{ll}
0 \text { - Non-existent } & 3 \text {-Defined } \\
1 \text { - Initial } & 4 \text { - Managed } \\
2 \text { - Repeatable } & 5 \text {-Optimized }
\end{array}
$$

Also it was possible to narrow the scope of evaluation to only central governments. If local governments were found to have their individual initiatives, they would be counted but not as important as a centralized initiative.

In terms of the level of integration on networking between central and local government, it is not enough to measure only the level of integration of the government. There was a need to implement a comprehensive architectural design or the very least, a standardized architecture framework to ensure inclusion of the local governments into the central system. Thus, we measured the presence or plan for an integrated enterprise architecture and common platform of these governments.

A parameter called "Public Management Reform by ICT" was included but was taken out this year. The reason being that there is already a similar parameter included within the Indicator called "Required Interface". In this indicator, there is a parameter for measuring online applications and e Payment system.

Enterprise Information System (EIS) was considered to be a more accurate terms for systems that governments owned or utilized as this would be more than just a few computers being connected together.
Ultimately, EIS would provide a technology platform that is central to the government and ensure that information can be shared across all functional levels and management hierarchies.

\section{National Portals}

\section{Trends and Developments}

The national portal is the foundation of e-Government and a basic interface for stakeholders to access government by electronic means. Most of the countries in the sample had established their portal very early and achieved a certain level of success. As for last five years, we used four dimensions as measurements: update frequency; public disclosure; link navigation system; and multi-language correspondence. Among the sample countries, the differentiation is getting closer and closer in terms of nation portal. On one hand, sample countries have put many resources to improve their portals. On the other hand, some indicators are losing their ability to distinguish such advances. Therefore, a new pattern or set of indicators is needed to test the new generation of national portal.

Moreover, rapid developments in the Internet have allowed service providers to provide faster connection speed and better quality of service during the past decade. This has allowed the government portals to provide more interactive and high quality multimedia content to the users; for example, users are now able to take virtual tours, listen to official speeches, and watch videos of public conventions. These services not only provide more contents to the user, but also narrow the gap between the government and its citizens. These have helped the recent governments to be more personalized and easier to approach than ever before.

Meanwhile, countries in all regions in the last five years have become more aggressive in addressing security and accessibility issues. This has been shown in a trend in National Portals having very specific security statements explaining policies on Security and Privacy. This is one way in which Governments can address the fears of their citizens (as well as international users) with regards to the security of their personal details should they try to use e-Government services.

Another trend is the increasing number of Accessibility Statements. These Accessibility Statements are very visible in Portals. They describe the specific features and/or standards which the portal meets to meet the special needs of disabled users. Accompany the trend of Accessibility Statements, National Portals are 
increasingly being included with design features which attempt to cater to the needs of disabled people.

An example is the Swedish National Government Portal. This portal provides an option to vocalize the messages via the Portal. There are also options which provide extensive customization options. These options include, being able to change the text size, line spacing, word spacing, font, text color and background color. Foreign languages translation(s) is also another trend. More and more National Portals provide documents in multiple languages.

\section{Methodology}

In order to develop a new set of indicators, it was concluded that a good national portal is the same as the private portal. Based on the assumption, a literature review on critical successful factors of portal has been conducted in order to figure out the proper indicators to measure the goodness of a national portal. After reviewing more than 20 related papers, it was determined there are four factors that affect portals significantly. The four factors are navigation, interactivity, interface and technical.

With regard to interfaces, 18 parameters were adopted to test the presence of a national portal. The layout, text, color and consistency are the main focus in this aspect, as well as the multi-language provision, print and multimedia functions. Taking United States and Philippines as examples, both countries get high scores in this category which means the interface of portal is fundamental in establishing a good portal.

In terms of navigation, 14 parameters are employed to test the basic functions of a portal, such site map, search engine, help function, and so on. As for interactivity, 15 parameters are employed such as a real contact information provision, e-mail function provision, SNS (social network service) or online community services, online polls and so on. Remarkably, we designed a cover letter which described the purpose of the survey and then sent it to webmaster. Within a certain number of days, a reply from the webmaster would count as one point.

In terms of technical aspects, 11 parameters were adopted to test the innovativeness of the portal such as RSS, Blog, sharing tagging and so on. Even though most of countries didn't establish these services or functions in their portal, these parameters are viewed as an innovations that a country may have enabled in their e-Government initiative.
Again, taking United Stated and Philippines as example, United Stated gets higher score in terms of three aspects than Philippines. With the pretest of United Stated and Philippines, the index has shown a significant discrimination, and the differentiation across countries is better.

\section{Forecast}

Since 2003, a wave of web-based services has been launched utilizing creative ideas, for example Wikipedia, Blogs and so on. These e-Services are based on the concept of the user as a producer of content, contacts, feedback and even applications, that is generally known as the stream of Web 2.0. Currently, the concept of Web 2.0 is being adopted in public sector more and more.

As the development of portals reached a certain level, the planners of e-Government are going to be pushed to put his/her efforts more on the new generation innovative e-services on the portal. With the concept of Web 2.0, a user-centric portal is going to come true innovatively and two consequences are emerging, one is the realization of cyber deliberative democracy, the other is the formation of knowledge society. However, some limitation is still existing, Public-Private-Partnerships (PPPs) for example. Since most of Web 2.0 applications are designed in accordance with commercial requirements they operate in a virtual world. Those applications have no physical form but are services or concepts which means governments have to put more effort on selecting and integrating those applications within their system. A new pattern of PPPs or so called cyber-PPPs is produced in this case. Governments need to collaborate extensively with private enterprises that created those innovative web services to provide a more sophisticated and integrated portal service in the future.

\section{Required Interface-Functioning Applications}

\section{Trends and Developments}

The availability of user-friendly and secure electronic services is the ultimate goal of e-Government initiatives.

The first strategies of electronic services delivery were guided by the knowledge of the functions and areas of responsibility of government agencies and were focused on online presence with gradual enhancement of the services. e-Tax and e-Tender were among the 
most widely implemented, while the rest of the services were quite different among the countries in terms of area of application, quantity and sophistication. Services were delivered through either websites of respective agencies or in case of more advanced countries, through one- stop-shop portals.

With the shift to user-oriented strategies for service delivery in the last years, many countries are catching up with the leaders and have visible results in offering much more diverse, advanced and comprehensive electronic services through one-stop-shop portals. As more uniform services are available online in the countries they can serve as a good base of comparison of their sophistication level among different countries. To ensure usability of offered services and trust to e-Governance, the countries are putting efforts to ensure secured transactions by adopting necessary legislation and introducing various security features. The only service that is lagging behind in its implementation is e-Voting, hampered by establishment of proper legislation and security issues.

\section{Methodology}

As electronic services are becoming more uniform between the countries in terms of diversity and delivery model, the earlier methodologies and evaluation has been found to be no longer feasible.

Instead of simply determining the presence of some online applications for government related transactions, it was decided to evaluate the extent of online applications by examining thoroughly the interactivity of that particular e-government service or application. Hence, it was decided that each online application should be explored if it is dynamic or just a static website where only information are posted on the web or whether it is a transactional or two-way interaction website which means that processing of documents or transactions are carried out online

Moreover, the scope of e-Government has been broadened to take full account of services that should be offered to citizens or the general public. The present evaluation system under the Required Interface category now includes 8 core e-Services such as e-Tender system, e-Tax systems, e-Voting, e-Payment system, Social Security services (involving payment of pensions, social benefits and insurance), Civil Registration services (securing birth, marriage certificates), Consular services (passports, visas) and Labor-related Services

For the e-Voting system parameter, the definition has been revised to cover not only Internet voting. It was decided to redefine e-voting to comply with the accepted definition of e-Voting which is voting by electronic means.

To evaluate this system the following measures are proposed:

0 - No plans/laws passed or formulated

1 - Laws are in place but not implemented

2-Onsite e-voting (polling kiosks, polling stations)

in selected localities

3 - Onsite e-voting in all localities

4 - Remote e-voting for national positions

5 - Remote e-voting for all elective positions

In addition to the evaluation criteria mentioned above, it was determined to include one significant criteria for the successful implementation of eGovernment initiatives which is the presence of $\mathrm{Cy}$ ber Laws (Cyber Security and e-Commerce Laws) and security system features to protect all transactions/activities across the Internet and among government offices and instrumentalities.

\section{Forecast}

Because societies are clearly moving towards increased participation in the environment they live in, applications allowing participation in decision-making are becoming more determinative in order to express citizen satisfaction. Regarding global environmental issues to take into account are public awareness and attitude to environment such as carbon footprints, competition and more aggressive actions to promote reducing carbon emission by means of each service.

In the concept of engagement of stakeholders such as private sector, NGOs, universities, community, and government; cyber laws and authentication systems comprehensiveness will shape the next stage of eGovernment.

Healthcare services must be also considered for future inclusion in the ranking as they serve as one of the major indicators of quality of life and help to cope with increasing uniformity of parameters among the countries.

\section{CIOs in Government}

\section{Trends and Developments}

CIOs (Chief Information Officers) in government are considered to be one of the key factors to the success of e-Government. Therefore, Waseda Institute of e- 
Government had included a set of CIO indicators since the first e-Government ranking in 2005. For the last five years, the category was evaluated with four indicators as following.

- Introduction of CIO: Implementation of CIO as the person responsible for ICT inside the structure of a government.

- Human Resource Development for CIO: a system or structure that allows the education, feedback and update of Human Resources in order to perform the tasks and functions for a CIO. This includes university programs, workshops and seminars.

- Supporting body for CIO: The cabinet or body that support the designed CIO in the development of his or her tasks. This support includes consultancy and assessment to the existing CIO.

- Role and function of CIOs: To indicate the existence of a framework that defines and establishes clearly what are the roles and functions of a CIO.

Awareness of the important roles of CIOs in eGovernment implementation is more and more increasing. Most of our sample countries designated CIOs (or equivalent titles) responsible for e-government. They also have programs for CIO development, bodies for supporting $\mathrm{CIO}$ and framework for $\mathrm{CIO}$ functions in certain levels. As a result, the differentiation regarding CIO between the countries is smaller and smaller.

Thus, the indicators of CIO in government are not as suitable as they were five years ago. These indicators can not sufficiently cover and evaluate CIO's roles and positions, CIO's activities in national level and subnational level. The improvement of these indicators is required, based on the principle of following, formal adoption and extending the previous indicator.

\section{Methodology}

Compared to the last rankings, the titles of indicator and sub-indicators were changed and a the checklist for each sub-indicator was made, which is sometimes based on some definitions from the last period.

The first sub-indicator changed from Introduction to CIO to CIOs presence. Corresponding to the definition used last year, that was decided the 'CIO presence' by 5 items and each item gets one point mark. One thing we would like to put emphasis on is the national CIO which is a person appointed by the highest official of the country. And it should be supported by document which can be a legal paper or announcements, news.
The second sub-indicator refers to CIO development programs, which was referred to as HRD for CIO. The title of the course need not have the words 'CIO' in the title but the content is related to 'CIO' issues. There are $\mathrm{PhD}$ courses in many areas such as technology or social-economics science but if the theme of a thesis is directed to CIO issues, it would be considered as this is a $\mathrm{PhD}$ degree being offered in CIO.

The next sub-indicator is CIO organizations earlier it was referred to as supporting body for CIO. In this indicator, if a country has a CIO studies organization, they would receive 2 marks as this is considered important for CIO studies.

The last is the CIO mandate which is related to the legal position of CIOs. This has been divided into 5 sub-indicators.

\section{Forecast}

The CIO position and role in the private sector is dramatically expanding in response to a highly unstable, competitive business market. The expansion has not only come in the aim of promoting efficiency, ensuring transparency, and for changing business models, but stems from requirements from society such as enhancing stakeholders' participation, streamlining entire value chains, and preparing for unforeseen crises. As the latter are also the essential roles of government, it is natural that its CIOs will soon be widely required to obtain and demonstrate wider competencies.

In the coming 5 years or so, the majority are expected to appoint legally-defined CIOs at all levels and establish training, consulting, and studying organizations as some leading countries already do. And the leaders will continue benchmarking, learning best practices, and then developing their CIO roles, leading to realization of a new type of organizational structure where CIO substantially plays key roles in both leading and sustaining all kinds of public services.

\section{e-Government Promotion}

\section{Trends and Developments}

For the past five years it is clear there has been a paradigm shift in e-Government development in countries worldwide. Countries have extended their eGovernment development from creating infrastructure policies and plans to introducing actual services to its citizens. In addition, countries have been promoting more services through government portal to build a 
closer relationship between government bodies and citizens. Although, these trends are manifested more clearly in developed countries, this is also reflected to a certain degree, in developing countries where infrastructure development is catching up and the need for more e-Government services is more pronounced than the demand for more infrastructures. As more countries build up their list of e-Services, countries have shifted promotion toward the use of e-Services rather than simply creating such services. That is, countries are not only informing its citizens the existence of these services, but encouraging the public to take advantage of these opportunitites. However, it is critical for countries to be aware and take careful steps in educating and informing its citizens to fully utilize these services, so they have the potential to move toward another stage of e-Government development.

Another important trend is the shift from centralized e-Government platforms to decentralization through the advent of e-Government at the sub-national level. This is manifested in the trend towards e-Local Governments such as the case of e-Municipalities. This shift from central government to local authorities is seen to increase the relevance of e-Government to the citizenry as more e-Government services are available and used at the local level. These shifts are also highlighted by the development of more localized e-Government strategies and policies that are becoming more significant in local communities. These in turn provide a foundation to support a more effective mechanism for governance through e-Government.

Lastly, it is clear that many governments have more precise structure of budgets applied for e-Government development. This is demonstrated in the movement toward local government development, which leads to greater distribution of budgets used for local government. Compared with previous years, local governments are receiving more funds and resource in carrying out e-Government services. Despite different stages of development among countries, governments most governments are now aware the importance of expanding services to more citizens to all parts of the countries.

\section{Methodology}

The scope of e-Government promotion includes the activities involved in supporting the implementation of e-Government; such as, legal frameworks, promotion activities, organizations/bureaus involved, budgetary distribution systems and the existence of third-party committees for over-sight evaluations.
The evaluation of e-Government Promotion indicators has been carried out by using a comprehensive list of evaluation parameters. This list is used to evaluate the degree of development in each section and to the current status of each country's e-Government promotion development. The use of comprehensive list provides a more balanced and equal weight of each area observed. Researchers may use it as a check list to identify whether countries have met each item.

Compared to the previous years, the parameters in eGovernment promotion have broadened and expanded greatly. These new parameters are allowing researchers to evaluate further in detail of each area related to the promotion of e-Government in all countries. In addition, researchers are able to identify and look into each issues surrounded by e-Government promotion to enhance the quality and provide a more accurate result of the changes and advances in implementation of each government during the previous past year.

\section{Forecast}

By observing previous results of the research and examining the trends of e-Government development in countries worldwide, there is the tendency for developed countries to invest and share the knowledge of the development of e-Government to developing countries; by doing so, developed countries may achieve other profits in return. Developed countries have the financial capacity and human resources to provide to developing countries, so that this may build closer relationship between them. With assistance of developed countries, developing countries will have greater potential in enhancing e-Government services; moreover, they will have a better chance to be exposed to numerous opportunities available. On the other hand, developed countries may improve their e-Services quality while in the process of assisting other countries.

From observations of past years, many countries have moved from concentrating on the development of e-Government in central government to local government. Examining this trend, it is possible to predict that greater amounts of financial resources and human resources will be distributed to local governments. As this expansion takes place, developing infrastructure and offering more services to its people, the overall utilization of e-services can be expected to increase significantly. As more services roll-out in countries, citizens will have better knowledge and be educated with the benefits that these services could bring to their lives. 
In conclusion, as government's investment in eGovernment increases the benefits citizens can be expected to receive substantial advancements. Taking the advantage of this enhanced technology, countries are better able to meeting the demands of their citizens with more services that might bring closer relationships together among the public and government.

\section{COUNTRY REPORTS}

In the following section, 34 countries of selected samples are described in terms of general information, e-Government status as well as trends in e-Government development.

\section{AUSTRALIA}

\section{General Information}

Australia is located in the South Pacific. It has a population of 21 million and a total land area of about 7.7 million square kilometers. Australia's GDP per capita is some US\$37,000. (IMF, 2007).

It is a parliamentary democracy. There are three levels of Government:; Federal (National) Government, State Governments (former Colonies) and Local Governments. To varying degrees, State Governments are responsible for transportation, health, environment, education, and emergency services. State Governments collect revenue and set their own budgets. The Federal Government is responsible for foreign affairs, national defense, currency, quarantine and immigration.

There are 23.28 broadband Internet subscribers per 100 people (ITU); 54.19 Internet users per 100 people (ITU) and 60.36 computers per 100 people (ITU).

\begin{tabular}{lc}
\hline Series Name & 2007 \\
\hline Internet subscribers (Total fixed broadband) & 23.28476 \\
per 100 inhabitants & 34.25222 \\
Internet subscribers (Total fixed) per 100 & \\
inhabitants & 54.18649 \\
Internet users per 100 inhabitants & 47.05161 \\
Main (fixed) telephone lines per 100 inhabitants & 102.4915 \\
Mobile cellular telephone subscribers per & \\
100 inhabitants &.. \\
Personal computers per 100 inhabitants & 20743178 \\
Population & \\
\hline
\end{tabular}

\section{e-Government Status by Indicators}

\section{Management Optimization}

In a 1997 policy statement titled "Investing for Growth", the Australian Federal Government set a goal to put all appropriate Federal Government services online. In 2002, the Government in its strategy titled "Better Services, Better Government" focused on improving online services. In 2006, in its strategy titled "Responsive Government: A New Service Agenda", the focus is on providing more integrated and connected services and transforming underlying Government processes.

\section{National Portal}

The National Portal of Australia has the web address "australia.gov.au". It is mainly a portal for Federal Government agencies although there are links to State Governments.

\section{CIOs in Government}

Australia formally appointed a Federal Government CIO in 2005. State governments have their own CIO. While there is collaboration of activities between the Federal CIO and State CIOs, State CIOs are answerable to their respective State Governments only and not to the Federal Government CIO.

There are many institutions in Australia which offer courses related to $\mathrm{CIO}$ development such Business Administration, Information Science, Information Systems and Computer Science courses.

\section{Required Interface}

The Federal Government provides numerous eGovernment services which include; e-Tender Systems, e-Payment, Social Security Systems, Civil Registration Systems, Consular Systems and Labor Related Systems. There are e-Voting systems available at secure locations for special voters.

\section{e-Government Promotion}

The Australian Government Information Management Office (AGIMO) is dedicated to the promotion of e-Government across Federal Agencies. Each State Government has e-Government promotion initiatives. While there is no legislation specifically for e-Government, there are laws which support eGovernment. The most important of these laws are for electronic transactions and cyber security. There are e-Government forums in the public and private sectors. Tertiary institutions offer e-Government related courses; either management or business oriented In- 
formation Management / MBA courses; technical Information Technology/Computer Science Engineering courses or Public Sector IT Governance courses. The Federal Government has an e-government strategy. It applies to all jurisdictions of Australian Government but especially Federal Agencies. State Governments have their own e-Government Strategies.

\section{Trends}

The Australian Federal Government in a press release in November 2008 signaled its intention to:

- "Enforce tighter whole of government ICT strategies, policies and spending through stronger ICT governance bodies at both the Ministerial and Agency Head level".

- "Whole of government ICT Strategies to be developed to include an ICT Human Resource Skills Plan and an Environmentally Sustainable ICT Plan".

- "Implement a common whole of government methodology which will allow each Federal Agency to self assesses their ICT capabilities and be auditable by a third party".

The government expects to realize significant cost savings after implementing these changes.

\section{BELGIUM}

\section{General Information}

Belgium is in Western Europe, bordering the North Sea, between France and the Netherlands. It has a population of around 10,403,951 with a growth rate of about $0.106 \%$. The total land area is approximately 30,158 square kilometers. The per capita GDP of Belgium is estimated at \$36,200 (as of 2007). (Source: https://www.cia.gov/library/publications/theworld-factbook/geos/be.html).

Belgium is a federal constitutional monarchy, where executive and legislative powers are divided between the federal government, 3 regions (Flanders, Wallonia and Brussels-Capital) and 3 communities (Dutch, French and German-speaking).

As of December 2007, there were approximately $5,490,000$ Internet users in Belgium or a penetration rate of $52.8 \%$. In addition, there were about 2,512,884 Broadband subscribers as of June 2007 or a penetration rate of about $24.2 \%$. (Source: www.internetworldstats. com).

\begin{tabular}{lc}
\hline Series Name & 2007 \\
\hline Internet subscribers (Total fixed broadband) & 25.96556 \\
per 100 inhabitants & 27.36572 \\
Internet subscribers (Total fixed) per 100 & \\
inhabitants & 49.91707 \\
Internet users per 100 inhabitants & 44.63458 \\
Main (fixed) telephone lines per 100 inhabitants & 97.83082 \\
Mobile cellular telephone subscribers per 100 & \\
inhabitants &.. \\
Personal computers per 100 inhabitants & 10457344 \\
Population & \\
\hline
\end{tabular}

\section{e-Government Status by Indicators}

\section{Management Optimization}

The Belgian e-Government strategy aims to create a single virtual public administration while respecting the privacy of users as well as the specificities and competences of all government bodies and administrative layers. Its main objective is to improve public service delivery for citizens and businesses by making it faster, more convenient, less constraining and more open.

The Federal Department of ICT (Fedict), in addition to its role of defining the eGovernment strategy, is also in charge of coordinating and ensuring the uniform and coherent implementation of this strategy within the federal administration.

The Federal Metropolitan Area Network (FedMAN) connects the administrations of 15 federal ministries and government services buildings in Brussels. FedMAN offers the federal civil servants with a shared high-speed network (broadband connection of $1 \mathrm{Gbps}$ ) and a number of related services supporting the delivery of eGovernment, including access to the TESTA (Trans-European Services for Telematics between Administrations) network of the EU.

\section{National Portal}

The federal portal (www.belgium.be) was launched in November 2002. It is both the institutional site of the Belgian federal government and an eGovernment portal providing a single and multilingual entry point to information and services provided by the federal government to citizens, businesses and civil servants. They have continuously developed newer version of the portal so as to reflect the specificities of the various Federal Government departments as well as ensure content and services quality, flexibility and user-friendliness. However, the government portal lacks some of the functions currently used by some individuals such as online forums, blogs and other SNS features. 


\section{CIOs in Government}

There is no specific law or mandate in Belgium creating the CIO position in the government. However, they have appointed the Minister for Enterprise and Administrative Reform to be responsible for the computerization of public services.

The Minister holds the responsibility for overseeing both the work of the Agency for Administrative Simplification and that of the Federal Department for ICT (Fedict), which is tasked with defining a common eGovernment strategy and ensuring the consistency and homogeneity of this policy.

Moreover, some universities in Belgium are offering graduate programs in Computer Informatics and ICT Management courses.

\section{Required Interface}

In terms of the required interfaces for e-Government, Belgium has more developed systems considering that they now have 20 basic government services that can be found online (12 for citizens, 8 for businesses) and most of them have reached a high level of sophistication ranging from two-way interactive websites and some are even transactional. They have a joint electronic public procurement portal (JEPP), an e-Tax systems and website where they can file Social Security benefits.

The Belgian Government also has adopted legislations to support the development of e-Government services. Among them are the Laws on Electronic Signature (2001), e-Commerce Law (2003) and the eCommunications Law (2005).

\section{e-Government Promotion}

In order to improve public services delivery for citizens and businesses, the Belgian government has adopted four main strategic streams for its e-Government program, as follows: 1) Re-engineering and integration of service delivery around user's needs and life events. 2) Cooperation among all levels of government so as to provide integrated services across organizational boundaries and administrative layers. 3) Simplification of administrative procedures for citizens and businesses. This requires an increased exchange and sharing of data and information between government departments and agencies. 4) Back office integration and protection of personal data.

The Federal Department of ICT (Fedict) is in charge of a uniform and coherent implementation of the e-
Government strategy within the federal administration. While the Crossroad Bank for Social Security (CBSS) supports the implementation of eGovernment services in the social sector. In particular, it supports the implementation of integrated services across all public institutions in dealing with social security aspects.

\section{Trends}

Since the creation of the Federal Department of ICT in 2001, several projects have been undertaken with regards to the promotion of eGovernment in the country. It has launched the federal portal in Nov. 2002 and continued its development programs in succeeding years. They have upgraded the eGovernment portal (Belgium.be) both in terms of contents and functionality. It also initiated various projects on improving the delivery of basic services to the citizens.

Some recent projects:

- The ePolice office (now operational at www.epol. be) or "Police-on-Web" service, allowing Belgian citizens to report a number of crimes to the police online 24 hours a day.

- The Be-Health platform (now online at www. behealth.be): an integrated platform aimed at delivering all health and healthcare related information and services online through a single portal.

- The Front Office Employment (for jobseekers)

- Electronic Birth Declaration

- Interoperability and Promotion of Open Standards

Source of Basic Information: http: epractice.eu (Belgium)

\section{BRAZIL}

\section{General Information}

Brazil, the largest South American country, has an area of 8.5 million square kilometers. Its population is approximately 180 million inhabitants (Urban: 81\%). ${ }^{1}$ The country's GDP per capita (based on Purchasing Power Parity) is USD 9705. ${ }^{2}$

The president executes policy approved by the 513seat Chamber of Deputies (the lower house) and the 81seat Senate (the upper house). Constitutional review

\footnotetext{
${ }^{1}$ http://www.brasil.gov.br/pais/sobre_brasil/.

${ }^{2}$ http://www.economist.com/countries/Brazil/profile.cfm?folder= Profile-FactSheet.
} 
is by an independent judiciary. Although the president can resort to temporary decrees to push through legislation, the 1988 constitution gives Congress ample capacity to frustrate the executive. A total of 21 political parties are represented in the lower house. ${ }^{3}$

According to the ITU, Brazil has the following Internet statistics. ${ }^{4}$

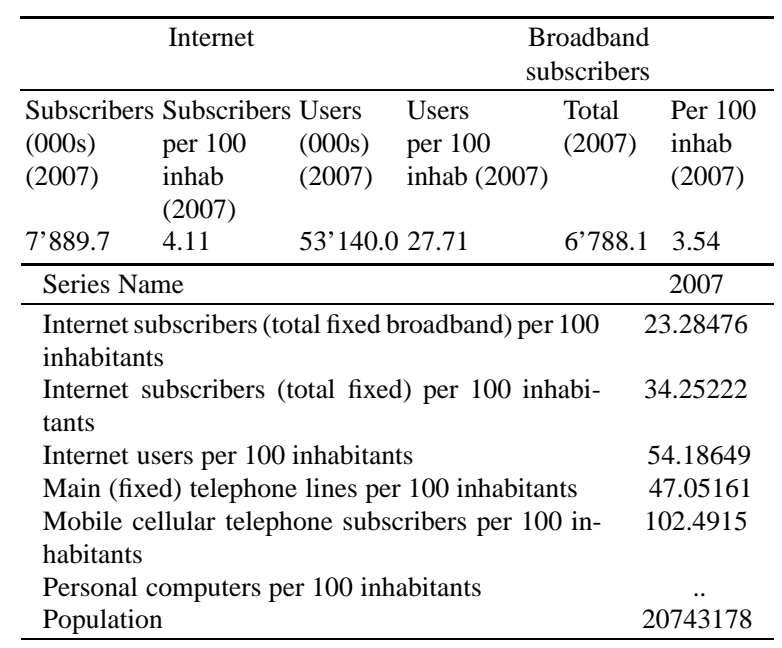

\section{e-Government Status by Indicators}

\section{Management Optimization}

The main Brazilian Directives on e-Government are: ${ }^{5}$

- Promotion of citizenship as a priority

- E-government and digital inclusion

- Open source software as a strategic resource

- Knowledge management as strategic tool when formulating and managing public policies

- Efficient usage of resources

- Common policies, rules and directives

- Integration between different levels of government

The e-Government strategy is the responsibility of the Ministry of Planning, Organization and Management.

Related to the adoption of an Integrated Enterprise Architecture, the government has started to interconnect the governmental offices. ${ }^{6}$

\footnotetext{
${ }^{3}$ http://www.economist.com/countries/Brazil/profile.cfm?folder= Profile-FactSheet.

${ }^{4}$ http://www.itu.int/ITU-D/icteye/Reporting/ShowReportFrame. aspx ?ReportName=/WTI/InformationTechnologyPublic\&RP_ int Year=2007\&RP_intLanguageID $=1$.

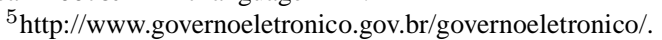

${ }^{6} \mathrm{http}: / / \mathrm{www}$.governoeletronico.gov.br/acoes-e-projetos/e-pingpadroes-de-interoperabilidade.
}

As for administrative and budgetary systems, there is a governmental page that centralizes this information: the Federal Service for Data Processing. The information on personnel management can be found at the SIAPENET web page and index.

\section{National Portal}

The government homepage http://www.brazil.gov. $\mathrm{br} / \mathrm{has}$ functionalities that allow for navigation. This homepage can be considered as an Information Portal. For specific procedures, The web page with information in English was not available.

\section{CIOs in Government}

There is no CIO position in the e-government legal framework. The President of the E-government Executive Council is Minister (Ms.) Dilma Vana Rousseff. The Executive Secretary of the E-government Executive Committee is Mr. Rogerio Santanna.

\section{Required Interface}

The government has a Portal for Information and Services (http://www.e.gov.br/). This portal provides links to the government agencies in charge of tenders, taxes, electronic voting, social security services, civil registration services, consular services, among others. These services are provided in a secure environment. The electronic payment feature is available at the time of our evaluation.

\section{E-Government Promotion}

The "E-Government Policy" was issued in year 2000 by the e-Government Executive Committee. In 2003, 8 technical committees for e-Government were created: Free software implementation, digital inclusion, system integration, legacy systems and software licensing, site and e-Services management, network infrastructure, G2G, and knowledge and strategic information management. The Ministry of Planning, Organization and Management (Ministério do Planejamento, Orçamento e Gestão) is also the Secretariat for this Committee. 


\section{Trends}

Although Brazil has established an e-Government program which is advanced compared to those of other countries in South America, it still faces the problem of inclusion, as the majority of its population cannot access these services. Regarding the usage of ICT for its public sector transformation, one of the main problems to be solved is the resistance to change.

\section{BRUNEI DARUSSALAM}

\section{General Information}

Gaining its independence in 1984, the State of Brunei is located on the north coast of the island of Borneo in Southeast Asia. With a population of less than 400,000 occupying a landmass of around 5,765 square kilometers, Brunei Darussalam is a monarchy, ruled by Sultan Hassanal Bolkiah since 1968. The Sultan is the head of state and head of government in Brunei, taking the role of the Prime Minister. Unlike many other former colonies of the British Empire, Brunei Darussalam is an independent sovereign Sultanate which is governed on the basis of a written Constitution and the Sultan has the absolute power. There is no elected legislative body and all Ministers are appointed by the Sultan at the pleasure of His Majesty.

Brunei Darussalam is the third largest oil producer in Southeast Asia and the fourth largest producer of liquefied natural gas in the world. With a GDP per capita of USD \$51,000 (as of 2007), the citizens of this small kingdom is one of the few countries in the world who do not need to pay any income tax.

\begin{tabular}{lc}
\hline Series Name & 2007 \\
\hline Internet subscribers (Total fixed broadband) & 2.866497 \\
per 100 inhabitants & \\
Internet subscribers (Total fixed) per 100 &.. \\
inhabitants & \\
Internet users per 100 inhabitants &.. \\
Main (fixed) telephone lines per 100 inhabitants &.. \\
Mobile cellular telephone subscribers per 100 &.. \\
inhabitants & \\
Personal computers per 100 inhabitants &.. \\
Population & 390058 \\
\hline
\end{tabular}

Currently implementing its 8th National Development Plan (from 2006-2008), the Brunei Government is emphasizing economic diversification through the development of export-oriented non-oil based industries. Under this Plan, 7.2\% (B \$526 million) of the total development budget was allocated to provide basic IT infrastructure. As of last year, the Internet penetration rate in Brunei Darussalam is less than $42 \%$ and only $3 \%$ of its users are using broadband to go online.

\section{e-Government Status by Indicators}

\section{Management Optimization}

The e-Government Strategic Framework was outlined by His Majesty Sultan Bolkiah, with the vision of "To be an e-smart government in line with the 21 st century civil service vision" and the mission for "His Majesty's Government aims to establish electronic governance and services to best service the nation".

Various infrastructure projects like the Prime Minister's Office Enterprise Data Center and Network Infrastructure (PMONet), Defense Infrastructure, Ministry of Foreign Affairs and Trade Network Infrastructure (MFANet) and many others were put into place within the last few years to integrate all the government ministries and agencies together.

\section{National Portal}

There are several portals within the Brunei Government aimed at providing information and services to its citizens. The main government portal is www.brunei.gov.bn, providing important information about Brunei Darussalam, which seemed to be targeting foreign visitors who want to know more about the monarchy.

Most of its citizen-centric and business-centric online services can be found at the Prime Minister's Office website. All portals within the Brunei Government are bi-lingual, using both English and the Malay language.

\section{CIOs in Government}

The formation of the e-Government Leadership Forum (EGLF) is chaired by the Deputy Minister at the Prime Minister's Office as the Executive Owner to e-Government and Chairman of the EGLF. The CoDeputy Chairman from the Prime Minister's Office is also appointed as the Overall e-Government Chief Information Officer (CIO).

In order to share the Ministries' experience in the implementation of e-Government Program/Projects and to highlight any issues arising to the EGLF, the Chief Information Officers' Dialog is held quarterly, chaired by the Permanent Secretary from the Prime Minister's Office and attended by one CIO from each Ministries. 


\section{Required Interface}

The Electronic Transaction Order was enacted in 2000 to protect the citizens of Brunei Darussalam and provide legality to electronic contract, electronic records and digital signatures.

However, due to the small population, the requirement for online public services is not in demand. These could be one of the main reasons for the unavailability of many of the G2C services, like the e-Payment services, e-Voting systems, online Social Security Services, Civil Registration Services and online Consular Services.

\section{E-Government Promotion}

The Initial Marketing Information Society Initiatives were undertaken which included the official launching of the e-Government program and all the media publicity and publishing frameworks (including policy, standards and best practices relating to e-Government).

\section{Trends}

Due to the fact that much of the information published by the Brunei Government or its e-Government websites (http://www.e-government.gov.bn, http:// www.bit.gov.bn, http://www.pomo.gov.bn, to name a few were not kept up to date, this has posed difficulties for researchers seeking details on e-Government projects, implementation progress and related information.

However, this does not diminish the improvement and progress that the Brunei Government has made so far. During the National Summit on Information Society (NASIS) in 2005, a new e-strategy paper was presented. Core strategies outlined in the paper served as guidelines on which the focus areas are to be embarked upon. The focus areas comprise of important factors such as e-Government, e-Business, e-Society, e-Agriculture, e-Employment, e-Environment and eScience. Slowly but surely the Brunei Government is marching ahead in its quest to perfect its e-Government initiatives.

\section{CANADA}

\section{General Information}

Canada, located in northern North America extends from the Atlantic Ocean to the Pacific Oceans. It covers an area of $9,984,670 \mathrm{KM}^{2}$ with a population of $33,389,000$ (28\% British origins and $23 \%$ French origins) in 2008. The capital is Ottawa located in the southeastern section of the country. It is a parliamentary democracy and constitutional monarchy. The monarch is HM Queen Elizabeth II; the governor general is Michaelle Jean, and the prime minister is Stephen Harper. The national language of Canada is English and French. The national currency is dollar (CAD). The national GDP (PPP) is around \$1.274 trillion and the GDP per capita is around $\$ 38,200$ in 2007.

According to ITU statistics, there are about 10 million Internet subscribers and 25 million Internet users in Canada. Moreover, there are about 9 million broadband subscribers in 2007. Canada is one of the leaders of eGovernment, delivering quality e-service to the public. It was ranked 3rd in the 2008 Waseda University World e-Government ranking.

\begin{tabular}{lc}
\hline Series Name & 2007 \\
\hline $\begin{array}{l}\text { Internet subscribers (Total fixed broadband) } \\
\text { per 100 inhabitants }\end{array}$ & 27.60369 \\
Internet subscribers (Total fixed) per 100 & 30.91309 \\
inhabitants & \\
Internet users per 100 inhabitants &.. \\
Main (fixed) telephone lines per 100 inhabitants & 55.48425 \\
Mobile cellular telephone subscribers per 100 & 61.67834 \\
inhabitants & \\
Personal computers per 100 inhabitants &.. \\
Population & 32876044 \\
\hline
\end{tabular}

\section{e-Government status by indicators}

\section{Management Optimization}

Canada has several strategic plans related to eGovernment, for example, the IM-IT Strategic Plan and IM-IT Investment Plan, both are under the Government Online (GOL), the officials responsible for eGovernment. The GOL website contains detailed information about each plan.

\section{National Portal}

The national portal (Canada.gc.ca) provides several functions that improve the communication efficiency between the government and the public. Moreover, 
it provides information that helps the public to understand the government structure better. This well organized portal serves as a platform that assists the public to find the desired information. To improve users' involvement, the portal also allows users to create government accounts, which allows each individual user to customize the portal as they desired.

Moreover, the multi-language portal widens the diversity of its users and includes functions that allow users to get up-to-date information instantly.

\section{CIOs in Government}

The presence of CIO is apparent in Canada. The Chief Information Officer Branch supports departments and agencies in developing and implementing strategies, policies and standards to improve the overall quality and value for money of government service delivery and internal operations.

\section{Required Interface}

Canada provides several interface functioning applications, for example, the e-Tax function and e-voting function. Canada Revenue Agency (CRA) provides online tax-filing options like NETFILE and EFILE. NETFILE allows users to file personal income tax and benefit return directly to the CRA using the Internet. However, this function only allows each individual to file their own tax. On the other hand, EFILE allows authorized service providers to send individual income tax return information to the CRA by Internet. The site also provides downloadable forms and tax-related information to the users.

E-Voting service has been made available for the public; for example, the 2005 Quebec municipal election allows the public to vote using electronic voting system. However, the outcome was largely criticized because of its expensive implementation and inaccurate results.

\section{e-Government Promotion}

The Canadian e-Government promotion is based mainly on IM-IT plans under the supervision of GOL. Since 1995, GOL has completed several missions including connecting to Canadians, improving efficiencies and generating savings, assuring security and privacy, and serving Canadians better. GOL will continue to serve as a leader for Canada's e-Government implementation.

\section{Trends}

For the past five years, Canada has changed from using Internet as a medium to provide public information to actually providing services to the public. Moreover, they have taken the issues raised by the Web community over the past few years to create the new Common Look and Feel Standards to reflect on the changes in technology. The standards comprise of standards on web addresses, standard on accessibility, interoperability, and usability of web sites, standard on common web page formats, and standard on Email. This has helped the Canadian government to provide consistent and predictable presentation of government services and contents to the public.

In conclusion, Canadian e-Government implementation is fairly sufficient; providing information and quality services to the public. According to Thomas Riley of eGov monitor, an important factor in the success of e-Government implementation is the strong leadership and proper funding from the Canadian government. With the continuation of support from the government, Canada will continue to be one of the top leaders of e-Government in the world.

\section{CHILE}

\section{General Information}

Chile is located on a coastal strip in South America. The country's GDP per capita (based on Purchasing Power Parity) is USD $13909 .{ }^{7}$

The political system is presidential, with a bicameral legislature that comprises a 38-seat Senate (the Upper House) and a 120-seat Chamber of Deputies (the lower house). The constitutional presidential term is four years and immediate re-election is not allowed. The judiciary is nominally independent, but in practice the executive exerts influence through the nomination of temporary judges and the control of promotions to the Supreme Court. Monetary policy is in the hands of an autonomous Central Bank. Chile has 13 regions, 51 provinces, and 343 municipalities. ${ }^{8}$

According to the ITU, Chile has the following Internet statistics. ${ }^{9}$

\footnotetext{
${ }^{7}$ http://www.economist.com/countries/chile/profile.cfm?folder= Profile-FactSheet.

${ }^{8}$ http://www.economist.com/countries/chile/profile.cfm?folder= Profile-FactSheet.

${ }^{9}$ http://www.itu.int/ITU-D/icteye/Reporting/ShowReportFrame. aspx?ReportName=/WTI/InformationTechnologyPublic\&RP_ int Year=2007\&RP_intLanguageID=1.
} 


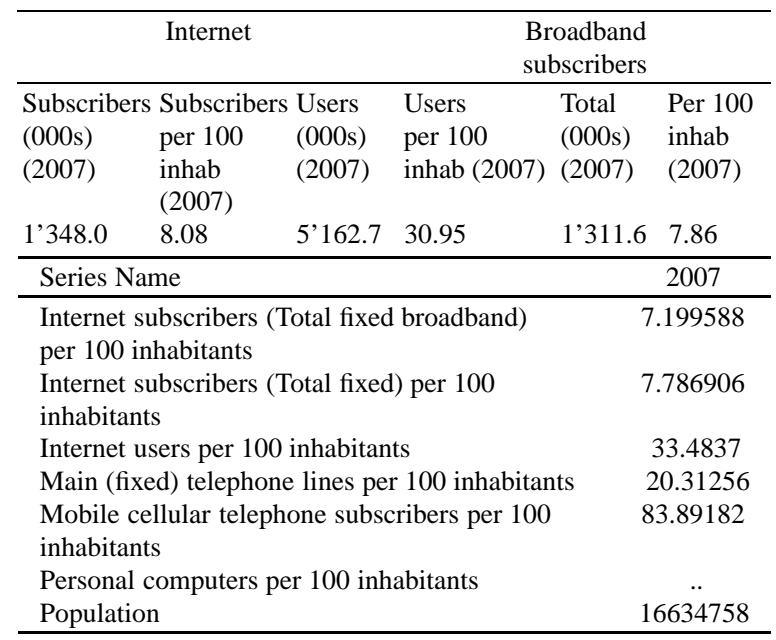

\section{e-Government Status by Indicators}

\section{Management Optimization}

E-Government development is seen as a key component in the state modernization process. Related to management optimization, the goal is to use ICT to improve and simplify institutional processes, creating channels to increase transparency and citizen participation.

The e-Government strategy is a part of the Chilean Digital Strategy 2007-2012 (Estrategia Digital Chile 2007-2012). The responsibility for this strategy is assigned to a Committee comprised by the Ministries of Economy (who heads it), Education, Presidency Secretariat, Finance, and Transportation/Telecommunications.

\section{National Portal}

The country's homepage is http://www.gobiernode chile.cl/, while the e-Services portal is the new 'Chile clic'. The official homepage has functionalities that are not found in other Latin American portals. What is more, a mail sent to the webmaster was replied to within a 3-day period. The web page with information in English was not available at the time of our evaluation.

\section{CIOs in Government}

There is no CIO position in the e-government legal framework, or the CIO position has not been considered by the existing legal framework. The Chilean Digital Strategy has a Council of Ministers in the top of the organization. This Council has an Executive Secretary (Mr. Patricio Gutierrez). The structure of this committee was approved by through a Presidential Decree.

\section{Required Interface}

The e-Services Homepage (http://www.chileclic. gob.cl/1542/channel.html) was launched on November 17, 2008. According to the government, this portal has information on 1500 services and provides access to 400 on-line proceedings.

The web page has two main categories: 'citizens' and 'businesses". The web page also displays the most popular searches. As in other governmental homepages, this portal has links to the government offices and agencies which are in charge of the proceedings.

\section{E-Government Promotion}

E-Government development is seen as a key component in the state modernization process. The goal is to use ICT to improve the services and information provided to citizens and organizations, to improve and simplify institutional processes, creating channels to increase transparency and citizen participation.

\section{Trends}

Chile is focused in a public sector reform having ICT as a key component. It is improving the existing channels to provide citizens and businesses with better services, efficiently provided. An e-Services homepage is part of ongoing efforts implement e-Government programs.

\section{CHINA}

\section{General Information}

People's Republic of China covers an area of $9,640,821$ square kilometers with a population of $1,321,851,888$ in 2007. Beijing, the capital is located in the northeastern China. China is a Socialist Republic with a single-party rule. The president of China is $\mathrm{Hu}$ Jintao and the premier of the state council is Wen Jiabao. The national language is Mandrian, or Chinese. However, there are many other languages used in regional areas like Cantonese, Shanghainese, Fuzhou, Hokkien-Taiwanese, Hakka, etc. The national currency is Renminbi (RMB) yuan. The national GDP (PPP) is around \$7.043 trillion and the GDP per capita is around $\$ 5300$ in 2007.

According to ITU statistics, there are about 150 million Internet subscribers and 210 million Internet users in China. Moreover, there are about 66 million broad- 
band subscribers in 2007. A host of web-based services have thrived, like network education, online banking, E-commerce, Internet advertising, IP telephone, online recruitment, etc. China is now the second largest Internet market in the world after the United States.

\begin{tabular}{lc}
\hline Series Name & 2007 \\
\hline $\begin{array}{l}\text { Internet subscribers (Total fixed broadband) } \\
\text { per 100 inhabitants }\end{array}$ & 5.002447 \\
Internet subscribers (Total fixed) per 100 & 11.3097 \\
inhabitants & \\
Internet users per 100 inhabitants & 15.80576 \\
Main (fixed) telephone lines per 100 inhabitants & 27.50563 \\
Mobile cellular telephone subscribers per 100 & 41.19176 \\
inhabitants & \\
Personal computers per 100 inhabitants &.. \\
Population & 1328629888 \\
\hline
\end{tabular}

\section{e-Government Status by Indicators}

\section{Management Optimization}

There had been several programs in the development of ICT in China. For example, the 10th 5 year plan, or the " 15 " took place from 2000-2005, focused on diffusion of information services (telephone, Internet) to rural areas. According to a representative from the Ministry of Industry and Information Technology of People's Republic of China (MIIT), the 11th 5 year plan is to focus on further development of the ICT infrastructure, improve information services to the public and minorities, and software standardization for ICT development in rural areas.

\section{National Portal}

The Chinese national portal provides a general gateway for users to access information released by the government. The national portal allows users to link to the portals of municipalities. In 2005,73 percent of China's local governments have their own gateway websites and 93 percent or more ministries have theirs. However, most sites are still in the stage of information publication, incapable of providing services to the public.

The national portal includes information about the government structure and also functions of each agencies. Moreover, the portal is provided in multiple languages (simplified Chinese, traditional Chinese, and English). The portal contains interactive pages that allow users to download application forms, search for information, and provides a platform for administrative departments to exchange information with one another.

\section{CIOs in Government}

The introduction of CIOs is growing popular in China, however, there is still a need for executive talent; therefore, there is a tendency for Chinese companies to invite CIOs from Western countries. As for the public sector, there is no specific mention of CIO.

\section{Required Interface}

Since 2005, the Chinese government has taken measures to provide users with a safe Internet environment. The Ministry of Information Industry has taken efforts to prevent fraud and other "unhealthy" activities on the Internet by requiring all Chinese-run website to register. There are also several cyber laws like Internet Broadcasting law, IP laws on Internet activities. The Chinese government has also taken measure to filter out websites concerning "inappropriate" contents.

According to the Chinese e-Government program in 2002, services like e-Taxation, e-Fiscal management, e-Public Security, e-Social Insurance system, eAgriculture, e-Audit system, e-Water conservancy, and government portal will be integrated. In 2003, the eTax Project was implemented. Under this project, China's private sector enterprises are required to produce on-line value-added tax invoices.

\section{e-Government Promotion}

Although China's current e-Government progress has not yet reached a high level of maturity, China is taking measures to cooperate with other more experienced e-Government nations to guide its e-Government implementation.

\section{Trends}

For the past five years, China has made important progress in the field of e-government. In 2005, Gov.cn, the official portal of the Central People's government of the PRC was constructed under the guidance of top Chinese leaders with the authorization of the National Informatization Leadership Group. This provides a gateway for the public to access government information services. Although the portal presently only provides information on the Chinese government, its programs, initiatives and services, will continue to increase the content of information and services to realize online interaction between government and citizens. 
China is currently catching up with other countries in terms of e-government implementation. Because of China's vast territory, it is difficult for diffusion of Internet. Therefore, to successfully implement egovernment in this vast territory, the country needs stronger leadership in the process. Moreover, further cooperation is needed among agencies and local government to allow interoperability between systems.

\section{FIJI}

\section{General Information}

Fiji is located in the South Pacific Ocean. It has a population of about 800,000 and GDP per capita of about US\$6,200. (CIA, 2006). The land area of Fiji is about 18,000 square $\mathrm{km}$.

There are about 80,000 Internet users (2007, ITU). And there are 7,000 broadband subscribers (2007, ITU).

Fiji under normal circumstances is a parliamentary democracy. The official head of state of Fiji is the President of Fiji.

\begin{tabular}{lc}
\hline Series Name & 2007 \\
\hline Internet subscribers (Total fixed broadband) &.. \\
per 100 inhabitants & \\
Internet subscribers (Total fixed) per 100 &.. \\
inhabitants & \\
Internet users per 100 inhabitants &.. \\
Main (fixed) telephone lines per 100 inhabitants & 12.92025 \\
Mobile cellular telephone subscribers per 100 & 52.10451 \\
inhabitants & \\
Personal computers per 100 inhabitants &.. \\
Population & 838699 \\
\hline
\end{tabular}

\section{e-Government Status by Indicators}

\section{Management Optimization}

The Fiji Government has only just launched a new e-Government program in May 2008. Most of its major ministries interlinked by a central network. There is a central Government IT Unit located inside the Fijian Ministry of Finance which manages this central network.

\section{National Portal}

The National Portal of Fiji has the web address fiji.gov.fj. It has links to government agencies and ministries throughout Fiji. The Portal in itself provides very basic functionality.

\section{CIOs in Government}

CIO level posts in the Fijian Government do not exist. There is a Director of ITC Services located in the Ministry of Finance which provides IT services for Government.

\section{Required Interface}

The Government of Fiji allows citizens the ability to download government forms from websites of various Government Ministries.

\section{e-Government Promotion}

Fiji has no formal laws mandating the implementation and/or use of e-Government services.

The University of the South Pacific whose main campus is based in Fiji and the University of Fiji have CIO related courses; either MBA or Information System type courses.

\section{Trends}

The government is at the stage of implementing basic infrastructure and including outing services online.

\section{FINLAND}

The Finnish state is composed of three administrative levels: the central level made up of national ministries and central authorities; the regional level consisting of 6 provinces, and the municipal level which has a high degree of sovereign power for policy-making. Finland has a low population density (17 inhabitants $/ 2 \mathrm{~km}$ ) and an economy heavily concentrated around Helsinki, Tampere and Turku, all of which are in the south of the country. Most other parts have lower rates of income and tend to suffer from emigration.

\begin{tabular}{lc}
\hline Series Name & 2007 \\
\hline $\begin{array}{l}\text { Internet subscribers (Total fixed broadband) } \\
\text { per 100 inhabitants }\end{array}$ & 30.64302 \\
Internet subscribers (Total fixed) per 100 &.. \\
inhabitants & \\
Internet users per 100 inhabitants & 68.22194 \\
Main (fixed) telephone lines per 100 inhabitants & 32.97394 \\
Mobile cellular telephone subscribers per 100 & 115.2193 \\
inhabitants & \\
Personal computers per 100 inhabitants &.. \\
Population & 5276895 \\
\hline
\end{tabular}

Sixty-nine percent (2007) of households and $99 \%$ (2007) of enterprises are connected to Internet, mostly through broadband (60\% (2007) for households and 91\% (2007) for enterprises). (Source: Eurostat) 


\section{e-Government Status by Indicators}

\section{Management Optimization}

The Finnish Government's Information Society Program initiated in 2003 came to an end in April 2007. Work on e-Government is being continued under the Ubiquitous Information Society project 2008-2011. The Ubiquitous Information Society Advisory Board chaired by the Minister of Communications was established to ensure the implementation of the national information society strategy as well as the aims outlined in the Government resolution. The Ubiquitous Information Society Advisory Board will report to the Government annually on the progress of key projects presented in the action programme. The Board has around 40 members from the involved Ministries, public administration, NGOs and business life. Measures will be taken to facilitate access to daily services, improve competitiveness and productivity, promote regional and social equality and secure the availability and quality of public services.

Finland has the joint intranet (Senaattori), which is an 'information directory' of all Finnish ministries, the Parliament and the Office of the President of the Republic, aimed at providing civil servants with access to Government and Parliament information, both internal and external. Senaattori underwent a continuous but slow development work with the systems integration. The new version aimed to offer a Government joint, interactive tool for knowledge management and a database that would constitute a coordinated whole with the Government and Parliament web services (intranet, extranet, Internet etc) and with joint internal systems, is still in process.

\section{National Portal}

The citizen portal 'Suomi.fi' provides a single access point to public information, administrative forms and online services. The portal features eServices and forms to download are linked to the business portal 'YritysSuomi.fi' ('EnterpriseFinland'), as well as Acts and Decrees for businesses that are linked to Finlex, the official law database. The citizen portal lacks some basic functions such as version for mobile phone and information about browsers and operating system, and some more advanced features such as multimedia shows, sharing, tagging, blog, podcasts etc.

\section{CIOs in Government}

The State IT Director is appointed at national level. Acting as a government-wide CIO, State IT Director heads a State IT Management Unit within the Ministry of Finance. The role and functions of IT Director and IT management Unit are described in respective governmental documents. A number of CIO related courses and programs are offered in Finland.

\section{Required Interface}

The basic legal framework for the e-Commerce is established in the Act on the Provision of Information Society Services which entered into force on 1 July 2002, enacting the EU Directive on electronic commerce (2000/31/EC) and the Act on the Protection of Privacy in Electronic Communications.

Finland has introduced many public e-Services. Such services as e-Tax, e-Payments, Social Security, and Labor services are fully transactional allowing full electronic case handling. Provision of the civil registration services online is considered to be not relevant in Finland, where birth and marriage certificates are not commonly used and therefore not needed by citizens. Public authorities have direct access to the Population Register, should they need information on a person's family status.

\section{e-Government Promotion}

E-Government documents state clearly the responsible departments for different tasks and projects. The Information Society Advisory Board provides assistance in monitoring Information Society developments and formulating and evaluating Information Society policies. Moreover in 2008 the private sector had to initiate an extensive evaluation project to develop and safeguard software and other information technology expertise in Finland. They are also some academic activities like seminars, conferences and research on e-Government in Finland.

\section{Trends}

Finland has been working on e-Government implementation since 1994, when the strategy for information management in government was adopted by the Finnish Government. To date Finland has achievements which include the introduction of the model of corporate management to state information manage- 
ment, an increased cooperation between state and local authorities in relation to Information Society issues. Unlike private enterprises, the civil usage of eGovernment services is quite low and immature which is clearly seen from the following statistics:

- Percentage of individuals using the Internet for interacting with public authorities: Obtaining information $43.2 \%$, downloading forms $31.0 \%$, returning filled forms $17.0 \%$ (2007)

- Percentage of enterprises using the Internet for interacting with public authorities: Obtaining information $88 \%$, downloading forms $91 \%$, returning filled forms $78 \%$ (2007)

High importance is attached to measures aimed at promoting the multi-channel, customer-, process- and regionally-oriented joint service reform in the Public Administration, and increasing connection speeds for information networks and ensuring the interoperability of the Information Society's infrastructure.

\section{FRANCE}

\section{General Information}

France is a unitary semi-presidential republic in Western Europe that covers an area of 551,695 square kilometers. ${ }^{10}$ The population is $63,753,140$ in 2008 with $0.5 \%$ annual increase approximately. As a member state of European Union, e-Government policies are coherent with Union action plans. France is economically one of the largest country with GDP in PPS (purchasing power standards) per inhabitant is $27,445 €$ as 2008. Total intramural R\&D expenditure (GERD) by sectors covers more than $2 \%$ of GDP. Percentages of broadband access by households and enterprises are $57 \%$ and $92 \%$, respectively as 2008 . Noting the 11

\begin{tabular}{lc}
\hline Series Name & 2007 \\
\hline Internet subscribers (Total fixed broadband) & 25.22411 \\
per 100 inhabitants & \\
Internet subscribers (Total fixed) per 100 & 27.67028 \\
inhabitants & \\
Internet users per 100 inhabitants &.. \\
Main (fixed) telephone lines per 100 inhabitants & 56.45009 \\
Mobile cellular telephone subscribers per 100 & 89.79798 \\
inhabitants & \\
Personal computers per 100 inhabitants &.. \\
Population & 61647376 \\
\hline
\end{tabular}

points increase since $2007,41 \%$ of individuals are using Internet for interaction with public authorities. ${ }^{11}$

\footnotetext{
${ }^{10}$ INS, French National Geographic Institute.
}

${ }^{11}$ Eurostat.

\section{e-Government status}

\section{Management Optimization}

Following the ADELE program (2002-2007), the General Review of Public Policies (RGPP) was launched by Prime Minister in July 2007. In the light of RGPP objectives the 'Council for the Modernization of Public Policies' (CMPP) has been instituted whose function is to decide on the necessary reforms in several fields of action related to the modernization of the French State. The Minister for the Budget, Public Accounts and Civil Service is the general reporter of the Council and owns the political responsibility for the e-Government policy. ${ }^{12}$

\section{E-Portal}

The France public portal site http://www.servicepublic.fr/ serves in a good balance of multi-frameworks and legibility. Citizen, Individual, and Business subdivisions have their own web sites which means elaborate content but may result in lack of integrity. However, in French there is much more information and functions than other 3 available languages.

Note: http://www.premier-ministre.gouv.fr/en is prime ministerial governmental portal site, real portal is http://www.service-public.fr/.

\section{CIOs in Government}

Despite the fact that French public administration does not have CIO titled position, the Director General of Directorate-General State Modernization is the head official who has national wide responsibility to coordinate, implement and support e-Government programs.

\section{Required Interface}

In addition to be one of the leading country adopted the Law on 'Informatics and Liberty', France has successfully legislated e-Government framework regarding EU Directives. For instance Procurement Code which is amended at 2006 states as from 1 January 2010 transmission of applications and tenders will be required in electronic format only. Due to citizens highly concern about privacy and increased security, sufficiency issues, France is adapting new generation of

\footnotetext{
${ }^{12}$ Facesheet: eGovernment in France, Edition 10.0, June 2008, European Commision.
} 
eID cards and Vitale 2 for healthcare. Except that personal documentation demanding citizen services such as passport and driver license, France has almost all agreed basic citizen and business services at highest level.

\section{E-Government Promotion}

France has enacted legal mechanism adequately and invested much in the promotion of e-Government but mainly at the national level. French society is prone to discuss and participate in community. There are some large platforms such as GIE SESAM-Vitale links health insurance system and healthcare professionals and Internet Rights Forum brings private companies, non-profit organizations, public authorities, and users together to discuss about online activities including eGovernment.

\section{Trends}

This is one of the successful national cases of implementation of e-Government framework. In the light of recent amendments and EU i2010 e-Government Action Plan, France will concentrate on reduction of public expenditures and enabling citizens and businesses to benefit with promoted participation. Main focus was on central government and citizens, but to achieve state's and union's goal, it is expected to accelerate Union-wide projects comprising non-French speaking individuals.

\section{GERMANY}

\section{General Information}

The Federal Republic of Germany has a land area of around 357, 021 square kilometers, it has a population estimated to be around 82.2 million as of 2007. The EU e-Government Report on Germany reports that $71 \%{ }^{13}$ of German households have internet access and has an internet user base of 50.4 million users. ${ }^{14}$ This marks a doubling of users from 2000 which only had 24 million users to what it is today. This sets the foundation for the demand for e-Government. Another important factor to be considered in analyzing e-Government is its strong federated states called Lander which also plays an important role in e-Government in Germany.

\footnotetext{
${ }^{13}$ www.eurostat.com.

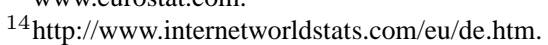

\begin{tabular}{lc}
\hline Series Name & 2007 \\
\hline Internet subscribers (Total fixed broadband) & 23.9711 \\
per 100 inhabitants &.. \\
Internet subscribers (Total fixed) per 100 & \\
inhabitants & 51.45311 \\
Internet users per 100 inhabitants & 65.07306 \\
Main (fixed) telephone lines per 100 inhabitants & 117.617 \\
Mobile cellular telephone subscribers per 100 & \\
inhabitants &.. \\
Personal computers per 100 inhabitants & 82599472 \\
Population &
\end{tabular}

\section{e-Government Status by Indicators}

\section{Management Optimization}

Germany almost scored a perfect rating in this area, having a relatively big Internet user base and having a relatively sophisticated base of users, Over the years the country has made alot of headway in building up its infrastructure such as Federal Administration Information Network thus paving the way for more optimization. This can be seen in the Implementation Plan 2008 of which (e-Government 2.0 is a programme), its plan for the implementation of its strategy for Innovations for Administration. The only downside is the lack of information available on the status of accessibility of human resources in the government.

\section{National Portal}

The design of the German portal (www.bund.de) reflects Germany's decentralized set up. The portal serves only as a gateway to other government websites that provides the service instead of directly providing it in the central portal. This results in a level of sophistication much lower than those of other national portals such as that of the United States. While the national portal might have shown lower levels of sophistication, it must be noted that there are government websites in Germany that show higher level of sophistication such as abilities to change font sizes and multimedia controls. It is forecasted that as Germany further enhances and optimizes their systems, standards across all government websites will increase in its level of sophistication.

\section{CIOs in Government}

There is a growing impetus by the federal government in the area of CIOs in government. This is in conjunction with the governments drive to optimize public administration. In early 2008, the New National IT 
Strategy comes into full force. This strategy aims to improve IT management in government. It foresees that each government department will have a CIO with wide ranging powers. It also results in the creation of a IT Council composed of CIOS that will tackle Germany's IT strategy issues. This development resulted in high marks for Germany in this area of the survey.

\section{Required Interface}

It has made a strong showing in the some of the key interfaces required such as in the area of procurement. An extensive list of other online services is also available and is being optimized.. With a federal structure, a number of functions which traditionally is performed by the central government has been devolved to the federal states. This means that each of the individual federated states and Municipalities are responsible for their own implementation of e-Government Projects. As a result a standard has been adopted called OSCI (Online Service Computer Interface) to facilitate e-Government data exchange.

\section{e-Government Promotion}

Germany has made strides in the promotion of eGovernment in the federal government but still lacks the necessary legal infrastructure to further promote eGovernment in the lower levels of government and in the federated states. This deficiency shows the need for more e-Government promotion at the lower levels of government and in the federal states.

\section{Trends}

Being a developed country it has much longer experience with e-Government and as such has a much more evolved e-government plan and targets. With several hundred online services already in place, the next step is the optimization and enhancement of these services. Also with its strong system of state governments, there is a need to strengthen or enhance e-government at this level to complement e-government initiatives in the federal government. This seems to be the direction of Germany: to enhance and expand e-Government to include the states and municipalities. This correlates with the shift from central government approach to a more decentralized approach in e-Government.

\section{HONG KONG SAR}

\section{General Information}

Hong Kong Special Administrative Region of People's Republic of China (Hong Kong) is a territory located on China's south coast on the Pearl River Delta. With 7 million people, Hong Kong is one of the most densely populated areas in the world. The GDP in 2007 is USD\$30,064 per capital.

As to ICT readiness, the Hong Kong Government (HKG) executed the Digital 21 IT strategy since 1998, and had obtained a fruitful achievement. $74.2 \%$ have their own computer, and $70.1 \%$ of them are able to access Internet. $64.8 \%$ of those who have Internet access get online frequently. As for e-Government, $37.6 \%$ of people know and use e-Government services.

\begin{tabular}{lc}
\hline Series Name & 2007 \\
\hline $\begin{array}{l}\text { Internet subscribers (Total fixed broadband) } \\
\text { per 100 inhabitants }\end{array}$ & 26.08537 \\
Internet subscribers (Total fixed) per 100 & 39.43858 \\
inhabitants & \\
Internet users per 100 inhabitants & 54.97296 \\
Main (fixed) telephone lines per 100 inhabitants & 53.76945 \\
Mobile cellular telephone subscribers per 100 & 146.4057 \\
inhabitants & \\
Personal computers per 100 inhabitants & 7206088 \\
Population & \\
\hline
\end{tabular}

\section{e-Government Status by Indicators}

\section{Management Optimization}

From 1998, the HKG started to implement the Digital 21 IT strategy, and revised strategies were set up in 2001 and 2004 respectively. In 2008, HKG launched a new IT strategy called "Digital 21", which emphasized on the new generation e-services, and a solid position for Hong Kong's economic.

During the past decade, HKG has achieved many goals in terms of e-government. One important achievement is establishment of the Office of the Government Chief Information Officer (OGCIO) in 2004 which is under the Commerce and Economic Development Bureau. Moreover, in the infrastructure aspect, Government Communication Network is built to connect all departments and agencies in 2000, and an advanced ip-v6 network has been implemented in 2008.

Two administrative applications had been established, one is e-Payroll \& Benefits System delivered by the Treasury Civil servants which users can make an 
online inquiry on their general payroll, appointment, payment-related and housing benefit information. The other one is e-Leave System delivered by Civil Service Bureau which is to support B/Ds in leave application, processing, calculation, recording and monitoring.

\section{National Portal}

The HKG launched a new portal (http://www.gov.hk) in 2008 which is no longer in cooperation with a private company but is operated by HKG itself. The new portal provides many kinds of services to not only citizens but enterprises and foreigners. Generally speaking, it has an excellent navigation function, and an easy to understand interface. In the portal is accessible in three languages: English, simple Chinese, and traditional Chinese. Layout and format for all government websites is found to be consistent. An auto-reply system of the portal allowing receiving immediate response from webmaster follows by official reply provided within 3 days from initial request.

Unfortunately, the government does not provide any public interactive systems in their portal like SNS, Forum and e-polls. The portal is merely viewed as a service tool by HKG.

\section{CIOs in Government}

The HKG established OGCIO in 2004 which is appointed at the ministry level. The main task of OGCIO is to provide leadership for the development of ICT within and outside the Government. In Hong Kong, many universities provide $\mathrm{CIO}$ related courses, but $\mathrm{CIO}$ organizations are relatively weak both in academic and private.

\section{Required Interface}

An Electronic Transactions Ordinance was enacted in 2000. It was the foundation of e-application which allows HKG to develop further e-services for users. So far, HKG has established e-Tax, e-Payment, consular services at transactional level; E-tender and civil registration services at two way interaction level; and social security and labor related services at downloading level.

\section{e-Government Promotion}

All activities are under Digital 21 IT strategy (19982007) and Digital 21 strategy (2008-2010). OGCIO plays the main role to enable the e-government promotion, video and pamphlet for example. Moreover, Digital 21 Strategy Advisory Committee is the main supporter for Digital 21 strategy, while Commerce and Economic Bureau provides the budget for e-government implementation and promotion, 4.5 billion HKD in 2008 for example. As for the assessment mechanism, HKG set an e-Government Steering Committee to assess the performance of e-government.

\section{Trends}

Hong Kong has adopted a pure service-oriented approach. Their main task was to integrate all services, employing ICT as a tool to promote their economy. A convenient ICT environment is considered to be a significant incentive for business operations. Before the Digital 21 strategy, HKG focused on infrastructure, human resources and culture. However, for the new strategy of Digital 21, their main tasks are: facilitating the digital economy; promoting advanced technology and innovation; developing Hong Kong as a hub for technological cooperation and trade; enabling the next generation of public services; and building an inclusive, knowledge-based society.

\section{INDIA}

\section{General Information}

India is located in Southern Asia, bordering the Arabian Sea and the Bay of Bengal, between Burma and Pakistan. The total population of India is approximately $1,147,995,904$ with a growth rate of around $1.58 \%$. Its total land area is approximately $3,287,590 \mathrm{sq} \mathrm{km}$. The per capita GDP in India is estimated to be $\$ 2,600$ as of $2007 . .^{15}$

India is a "Sovereign, Socialist, Secular, Democratic Republic" with a parliamentary system of government. It has 28 states and 7 union territories. India is capitalizing on its large number of well-educated people skilled in the English language to become a major exporter of software services and software workers.

\footnotetext{
${ }^{15}$ https://www.cia.gov/library/publications/the-world-factbook/ geos/in.html.
} 
As of September 2007, there were about $60,000,000$ Internet users in India ( $5.2 \%$ penetration rate) and around 3,130,000 broadband subscribers. ${ }^{16}$ In addition, the number of mobile phone subscribers in India is estimated to be approximately 296 million.

\begin{tabular}{lc}
\hline Series Name & 2007 \\
\hline $\begin{array}{l}\text { Internet subscribers (Total fixed broadband) } \\
\text { per 100 inhabitants }\end{array}$ & 0.267746657 \\
$\begin{array}{l}\text { Internet subscribers (Total fixed) per 100 } \\
\text { inhabitants }\end{array}$ & 1.153962493 \\
Internet users per 100 inhabitants & 6.928907394 \\
Main (fixed) telephone lines per 100 & 3.371469498 \\
inhabitants & \\
Mobile cellular telephone subscribers per & 19.98433685 \\
100 inhabitants &.. \\
Personal computers per 100 inhabitants & 1169015552 \\
Population & \\
\hline
\end{tabular}

\section{e-Government Status by Indicators}

\section{Management Optimization}

The government has started implementing the National e-Governance Plan (NeGP) which is composed of 27 Mission Mode Projects and 10 components. These mission mode projects (MMPs) have been identified on the basis of high citizen/business interface covering a wide range of core services offered by the department.

The Department of Information Technology which is under the Ministry of Communications and Information Technology is responsible for the implementation of the National e-Governance Plan.

Among their core support infrastructure is the State Wide Area Networks (SWANs) covering the 29 states and union territories providing a $2 \mathrm{Mbps}$ intranet connection that extends up to the Block level. They also have the State Data Center for the States to consolidate services, applications and infrastructure to provide efficient electronic delivery of G2G, G2C and G2B services.

\section{National Portal}

The government portal (http://india.gov.in) is maintained and developed by the National Informatics Centre which under the Department of Information Technology.

\footnotetext{
${ }^{16} \mathrm{http}: / / \mathrm{www}$. internetworldstats.com/asia.htm\#in.
}

The Portal has been developed as a Mission Mode Project under the National E-Governance Plan of the Government. The portal provides a single window access to the information and services being provided by the Indian Government for the citizens and other stakeholders. This Portal provides comprehensive, accurate, reliable and one stop source of information about India and its various facets.

The portal has good navigation features but lacks some aspects particularly in providing venues for interactive forums or discussion sites.

\section{CIOs in Government}

There are no specific laws or mandates for CIO positions in India. However, they have a Minister of the Department of Information Technology (DIT) whose functions are similar to a CIO in the government. The DIT is responsible for the promotion of IT enabled services and also on policy matters relating to e-Governance and Information Technology.

There are no CIO associations in India but some universities are offering graduate programs in Information and Communication Technology.

\section{Required Interface}

In terms of the required interface, most government core services can be accessed, but they have not yet reached a higher level of sophistication as most of the sites only allow downloading of forms. Only the eTax system is transactional where the citizens are able to file their taxes online. Meanwhile, the government has already implemented the use of e-voting machines since 2004.

\section{e-Government Promotion}

The government has been implementing their National e-Governance Plan (NeGP) with the common vision of providing better and accessible public services to their citizens. They have given the Department of Information Technology the tasked of coordinating and implementing various government projects related to the successful implementation of the said plan.

As part of their implementation strategy, they have adopted an integrated approach to make sure that eGovernance will be promoted as a Centralized initiative, to the extent necessary, to ensure citizen service orientation, to realize the objective of interoperability of various e-Governance applications and to ensure op- 
timal utilization of ICT infrastructure/ resources. Further, they have promoted Public Private Partnerships wherever feasible to enlarge their resource pool considering that such program would need sufficient funding support to realize their goals.

\section{Trends}

The Government has been aggressive in the area of developing the core support infrastructure for their web-enabled services to realize their vision of making all government services accessible to everybody.

They plan to augment the installation of some 100,000 Common Service Centers in rural India and 10,000 in urban India. These CSCs are equipped with broadband internet enabled kiosks for delivery of government and private services to citizens. Each CSC is expected to service a cluster of around 6 villages. As of September 2008, 17,775 Common Service Centers have been rolled out.

State Data Centers, one core infrastructure for supporting e-Governance initiatives are to be established to consolidate services, applications and infrastructure to provide efficient electronic delivery for $\mathrm{G} 2 \mathrm{G}, \mathrm{G} 2 \mathrm{C}$ and G2B services. This service delivery platform is programmed to be ready in most states by March 2009 .

\section{INDONESIA}

\section{General Information}

Indonesia is the world's largest archipelagic state and home to the world's largest Muslim population. It is located in Southeast Asia and covers 17,508 islands, it is in a strategic location astride or along major sealanes from Indian Ocean to Pacific Ocean. here are five large islands in Indonesia; they are Sumatera, Java, Borneo/Kalimantan (the 3rd biggest island in the world), Sulawesi and Papua. There are 33 provinces, 440 districts and 5,263 municipalities with 62,806 villages. The national language is the Indonesian language, with 583 dialects across the country.

This strategic location has a significant influence towards its Culture, Social, Politics and Economy. The GDP is USD 865 billion in 2007. Indonesia's annual economic growth is $6 \%$. The country is the world's 4th most populous country with the most populous Muslim-majority nation (85\%).

Based on the data from ITU, Indonesia has only $5.61 \%$ of Internet users who get online frequently. From those Internet users, only $1.35 \%$ who are subscribed to Internet connection and $0.11 \%$ are using broadband network to access the Internet. The cellular phone penetration rate is about $43 \%$ of population and $4 \%$ have fixed line connection. ICT facility is not yet affordable to the majority of the population. The cost of distributing access and technology is still high in some areas.

\begin{tabular}{lc}
\hline Series Name & 2007 \\
\hline $\begin{array}{l}\text { Internet subscribers (Total fixed broadband) } \\
\text { per 100 inhabitants }\end{array}$ & 0.110738397 \\
Internet subscribers (Total fixed) per 100 &.. \\
inhabitants & \\
Internet users per 100 inhabitants & 5.612472057 \\
Main (fixed) telephone lines per 100 inhabitants & 7.696825027 \\
Mobile cellular telephone subscribers per 100 & 35.33033752 \\
inhabitants & \\
Personal computers per 100 inhabitants &.. \\
Population & 231626976 \\
\hline
\end{tabular}

\section{e-Government Status by Indicators}

\section{Management Optimization}

An e-Government initiative was started in 2001 and after the launching of the President Decree No. 3 in 2003, regarding the Policy and National Strategy of e-Government Development. The Blueprint of eGovernment Implementation was launched in 2006. Since then, other regulations have been established, such as the Guidelines for Government's Portal Infrastructure Development, Electronic Record Management, Technical Training and Education, Website Management, e-Government's Project and Budget Implementation, e-Government's Standard Quality, Services and Application Development, Handbook of Local Government Websites, etc.

Currently, the Blue Print's has main components, where some of them are:

- Toward Indonesian Information Society in 2015 (MII 2015)

- Palapa Ring Project: Information InfrastructureFiber Optic Project Networking national wide will be started in November 2007

With this blueprint, it is expected that the e-Government and ICT development will be more enhanced in infrastructure, education, legal, application and its supporting elements.

\section{National Portal}

The portal of Republic Indonesia (www.indonesia. go.id) is the first link to connect to every institution re- 
lated to governments. This website will take the users to those government's related links to get the government's services. However, this portal is considered a simple one and requires improvements in certain areas to be more user-friendly and provide the features for the disabled. The portal is in English and Indonesian and provides standard features only. Compared to previous years, some information and enhancements have been added related to the links and features.

\section{CIOs in Government}

The CIO function in the government is conducted by the Ministry of Communication and Information. The CIO is appointed at national level and there are some CIOs at the bureau level, province level and district/municipal level.

There are some CIO development programs and since 2002, there have been 35 groups of ICT training program, conducted by Ministry of ICT for senior level officers. Also, there are some human resources centers in universities, Vendor Training Center and Private Training Center in collaboration with the Ministry of ICT.

\section{Required Interface}

The basic legal framework for the Cyberlaw was established in 2008 while the IPR Law was enacted in 2003 There are many applications, and some of them allow user transactions such as e-Tender system and eTax system with e-Payment system. Others services allow the downloading of forms, such as for Tax services, Tender services, Payment services, Civil registration, Consular services, Labor services.

\section{e-Government Promotion}

There are some Legal Mechanisms for promoting eGovernment, such as the Presidential Instruction that contains the five-year National Information and Communications Technology Action Plan for Indonesia, also the Presidential Decree concerning the ICT Coordinating Team, another Presidential Instruction concerning National Policy on EGovernment Development. On Cybersecurity and Counter-Cybercrime measures, MICT established the ICT Security Task Force (ICT-TF) and finalized the new Cyberlaw, which is called "Electronic Information and Transactions Law" in 2008 .
There are many related activities like seminars and conferences to promote the e-Government policy. Also, some private groups and academic societies are involved to play the role of enablers of e-Government promotion.

There is a CIO Council which acts as oversight body. Most evaluation from e-Government activities come from independent non-government organizations or individual critics who has expertise or interest in e-Government, such as ICT watch.

\section{Trends}

Indonesia continues to develop e-Government. EGovernment is considered to be an important solution for government services to be provided to the citizens. Some improvements were shown as a result of the dedication of the government to the development of the e-Government. From position 29 last year, Indonesia has improved to number 22.

Challenges to expansion of e-Government involve restricted budget and funding, limited qualified HR, limited infrastructure and the awareness and concerns of the local leaders. However, some efforts have been made to overcome such challenges.

\section{ITALY}

\section{General Information}

The Italian Republic has a land area of around 301,338 square kilometers, it has a population estimated to be around 59.6 million as of 2008. The EU eGovernment Report on Italy reports that $43 \%{ }^{17}$ of Italian households have internet access and has an internet user base of 32.2 million users. ${ }^{18}$ This is a $250 \%$ increase from 13.2 million users in 2000 . While there is tremendous growth in internet users, it still lags behind other European countries like Germany in terms of Internet use.

\section{e-Government Status by Indicators}

\section{Management Optimization}

Italy has well developed plans and strategies for management optimization which covers both central gov-

\footnotetext{
${ }^{17}$ www.eurostat.com.

${ }^{18} \mathrm{http}: / /$ www.internetworldstats.com/eu/it.htm.
} 


\begin{tabular}{lc}
\hline Series Name & 2007 \\
\hline Internet subscribers (Total fixed broadband) & 18.4452858 \\
per 100 inhabitants &.. \\
Internet subscribers (Total fixed) per 100 & \\
inhabitants & 54.35074615 \\
Internet users per 100 inhabitants &.. \\
Main (fixed) telephone lines per 100 &.. \\
inhabitants & \\
Mobile cellular telephone subscribers per &.. \\
100 inhabitants & 58876836 \\
Personal computers per 100 inhabitants & \\
Population &
\end{tabular}

ernment and regional governments. In 2007 it established the Public Connectivity and Cooperation System which connects most of the central government offices. The networks of regional governments will also be connected. It is only in the area of human resource management that there seems to be a lack of central facilities, this may be explained due to decentralization.

\section{National Portal}

The Italian portal (www.italia.it) is geared towards its citizens and does not provide the site in other languages except for Italian. The portal also reflects a more decentralized approach in portal design where the portal only acts as a gateway to other sites that provide the services instead of the portal itself housing all e-Government capabilities. This paradigm can be attributed to the decentralized nature of the Italian government. The portal also is not very sophisticated in the technical aspect as it seems to shy away from sophisticated technical features which is probably due to the consideration that only $25 \%$ of its households have broadband access. With the growth of broadband use, it is expected that the level of sophistication of the Italian portal will also increase as internet users will have more broadband access.

\section{CIOs in Government}

The establishment of CNIPA as the de facto CIO office of the Italian government manifests the recognition of its importance in government. But on the other hand, additional legislation to institutionalize such a position in government is still needed to further promote CIOs in government in various levels. It is interesting to note that while there are no clear mandates yet for CIO some local governments have established such positions as is the case of Milan.

\section{Required Interface}

Italy has passed requisite legislation such as cyber security laws and an e-Commerce law. This paves the way for the implementation of the identified core government interfaces. It must also be noted that there is a move to phase out some of these traditional services such as the issuance of certificates such as the case of civil registration. This will eventually result in the phasing out of this service altogether. Another important aspect is the devolution of payment facilities to websites of concerned agencies instead of a centralized payment gateway as is the case in more centralized governments. This manifests the trend towards decentralization of services to be more reflective of the actual structure of the government.

\section{e-Government Promotion}

The adoption of the e-Government Code in 2006 marked a milestone in Italian e-Government efforts. Passage of such legislation heralded stronger emphasis of e-Government in Italy. This also provided the legal framework for succeeding e-Government initiatives both at the national and local levels.

\section{Trends}

The enactment of the e-Government Code provided Italy with new drive for e-Government. As its digital infrastructure becomes more mature it is expected that e-Government in Italy will move forward and expand to the regional governments. With decentralization, it is expected that there is a shift from services provided by the central government to those of regional governments. An aspect of the resulting public administration reform is the phasing out of certificates. As more and more services become online, the need for paper certificates will be diminished and there will be a shift to electronic verification for government.

\section{JAPAN}

\section{General Information}

Japan is situated off the eastern coast of the Asian continent. The nation's roughly 7,000 islands extend in an arc of about 3,000 kilometers northeast to southwest. The land area is $377,923 \mathrm{~km} 2$, consisted mainly of mountainous areas (61.0\% of all lands). The population is $127,687,000$ as of April 2008. The aging trend 
has moved forward with the declining birthrate and a growing proportion of elderly people since 1997.

The ICT infrastructure is well-established and widely-covered: $95.8 \%$ of households have access to and $75 \%$ of the populations use at least once the Internet in 2008. Japan also has wide-spread broadband infrastructure with 30 millions in 2008, especially FT$\mathrm{TH}$, the subscriptions reached at 14 million in 2008, an increase of $20 \%$ from the previous year.

The real GDP of the ICT industry in 2006 is 69.7 trillion yen and the ICT industry is the largest industry among all industries, accounting for around $12.5 \%$. However, Japanese companies are more or less reluctant to go out into overseas markets unless they hold large shares domestically. This is because the domestic market is highly competitive, which keeps the business size per company small, and they cannot enjoy economies of scale to start businesses abroad.

\begin{tabular}{lc}
\hline Series Name & 2007 \\
\hline Internet subscribers (Total fixed broadband) & 22.4665966 \\
per 100 inhabitants &.. \\
Internet subscribers (Total fixed) per 100 & \\
inhabitants & 68.85384369 \\
Internet users per 100 inhabitants & 40.03541183 \\
Main (fixed) telephone lines per 100 inhabitants & \\
Mobile cellular telephone subscribers per 100 & 83.88040924 \\
inhabitants & \\
Population & 127966712 \\
\hline
\end{tabular}

\section{e-Government Status by Indicators}

\section{Management Optimization}

The full implementation of e-Government began with "e-Japan Strategy" in 2001. Under the strategy which focused on building infrastructure to promote the on-line application for governmental services, the network among ministries and between central and local government, the governmental public key infrastructure, and the legal framework were established. In 2003, the government started the electronic signature and authentication service. As a next stage, "e-Japan Strategy II" was adopted in 2003. It focused on the IT enabled operations and services. The government adopted the Enterprise Architecture approach and accordingly the ministries, who had developed their systems individually, reviewed their business processes and systems. While each ministry made its own optimization plan, the shared plans for establishing common business processes and systems among ministries were also developed. In 2006, "New IT Reform Strat- egy" was developed as the third stage to accelerate online application and optimization and to realize a onestop on-line service in the future. As of 2008, most of the 84 areas of optimization targets are in the design phase.

\section{National Portal Service}

The national government's "e-Gov" portal site provides the overall information gathered from the portals run by each ministry. Citizens can obtain information if they just access to the "e-Gov" portal. The portal is user-friendly on the whole, but it lacks support for foreigners and disabled people. Government on-line services coverabout 1200 items including e-tax.

\section{CIOs in Government}

All central ministries have CIOs who are appointed from the internal senior staff and assistant CIO who is an expert recruited externally. The percentage of the CIO appointment at the prefecture level is $75 \%$ and $30 \%$ at the city level. To promote the CIO appointment at the local level, the national government developed and has carried out a CIO training program.

CIO s capacity building for training are held in only a limited number of institutions such as Waseda University and the Japan Society of CIO.

\section{Required Interface}

Online application systems such as e-Tax, ePayment, and social security services provide transactional operation (covering all the service processes including requests, payments, decisions, delivery). Citizens must obtain an electronic signature and authentication prior using the systems. e-Government Promotion.

The New IT Reform Strategy and the frameworks of action plans were set up by IT Strategic Headquarters. It has the subordinate organs including the CIO Council consisting of all Ministry CIOs and Assistant CIOs Council.

As for evaluation, an e-Government Evaluation Committee consisting of the external IT experts was established in 2006 to thoroughly assess and evaluate the optimizations carried out by each ministry.

\section{Trends}

The government has steadily made efforts to expand the utilization of on-line services as a main part of thee-Government initiative since 1999. In 2005, the 
online application at the national level covered $96 \%$ of all the administrative procedures. But the use of this online application was only $35 \%$ in 2008 . To enhance e-Government, the government is making a new action plan to improve the on-line applications for the further promotion of their use.

\section{KOREA}

\section{General Information}

Korea is located in South East Asia with Seoul the capital, the largest city of Korea, and the second largest metropolitan city in the world.

Korea has made great headway in technologies such as in aerospace, robotics, and communication technologies. Korea has a space research institute of which Russia is a partner. Korea also has a well developed communication technology; the country remained top in ranking in Internet use, internet penetration, broadband penetration, mobile phone ownership, $3 \mathrm{G}$ mobile telecoms, WiFi hotspots and WiBro. Korea continues to develop its communication technologies and striking to achieve a ubiquitous network society in 2010.

\begin{tabular}{lc}
\hline Series Name & 2007 \\
\hline Internet subscribers (Total fixed broadband) & 29.44168 \\
per 100 inhabitants & \\
Internet subscribers (Total fixed) per 100 & 29.44168 \\
inhabitants & \\
Internet users per 100 inhabitants & 73.80165 \\
Main (fixed) telephone lines per 100 inhabitants & 49.57122 \\
Mobile cellular telephone subscribers per 100 & 90.19922 \\
inhabitants & \\
Personal computers per 100 inhabitants &.. \\
Population & 48223856 \\
\hline
\end{tabular}

\section{e-Government Status by Indicators}

\section{Management Optimization}

Korea began their national IT strategies years ago. Currently, their national strategy, Ubiquitous Master Plan Korea, aims to increase broadband usage, increase national GDP, implement IT services in eight major industries, and provide services to citizens anytime, anywhere and by anyone. South Korea has a well organized plan to be achieved by 2010 .

\section{National Portal}

Korea's portal site provides services for citizens, latest news, basic facts about the country, and posts links of links to related departments and agencies. The website is in Korean and seven other languages. The web- site provides almost all information Korean citizens or visitors would need to know about Korea; Korea's daily news, updates from cultural center and stories provided by Korean government. However, the site would be better by adding blogs, tag sharing, and background color change.

\section{CIOs in Government}

CIO was introduced in Korea in 1998; currently, a CIO position in the ministry level, yet not in prefecture level. In 2004, the responsibility of CIO became critical due to the increase of e-government services in Korea. Part of CIO's role include managing IT-related issues, e-government services, budgeting, manage staffing and aggressively process reengineering processes. The government has a CIO University, which provides courses, documentations, and information related to the position of CIO. There are also a number of universities providing CIO certifications and programs for businesses.

\section{Required Interface}

The official government homepage went online in 1998. E-government services included real estate registration, internet-based civil services and information for citizens. Currently, the government has a several e-Government projects underway; including, eProcurement system, home tax system, education information system, personnel policy support system, e-Approval, e-Documents, and promotion of an eSignature system.

\section{e-Government Promotion}

In 2001, "The Promotion of Digitalization of Administrative Work for E-Government Realization Act" was passed to focus on e-Government service developments. The Presidential Committee on Government Innovation and Decentralization was formed as an organization to implement plans around presidential agenda. In 2003, "The Participatory Government's Vision and Direction of E-Government", "E-Government Roadmap" were released and Korea was able to increase online public services to $87 \%$, it has remained in the top 10 ranking in world e-Government service ranking, and has reduced the citizens need to visit government office for civil service issues. 


\section{Trends}

Korea has been developing numerous e-Government services in the past few years and has developed a stable national IT strategy plan. Currently, Korea continues to progress and move forward in achieving its Ubiquitous Master Plan aiming to be achieved in 2010. Korea seeks for more broadband users, through the usage of IT services to increase gross income, create more job opportunities, and provide superior IT services to its users. Specific developments include, e-Procurement system, e-Signature system, enhancing tax service system, and integrating social security information systems.

\section{MALAYSIA}

\section{General Information}

Bordering Thailand, Indonesia, Singapore, Brunei and the Philippines, Malaysia is situated at the center of South-East Asia, with a total landmass of 329,847 square kilometers $(127,355 \mathrm{sq} \mathrm{mi})$. It is the home of 27.73 million (as of Sept 2008) Malaysians of various different races. As a former British colony, the Malaysia government is closely modeled after the Westminster parliamentary system and thus is headed by a Prime Minister. Malaysia's GDP per capita is USD\$6,956 (as of 2007).

\begin{tabular}{lc}
\hline Series Name & 2007 \\
\hline $\begin{array}{l}\text { Internet subscribers (Total fixed broadband) } \\
\text { per 100 inhabitants }\end{array}$ & 5.15168667 \\
Internet subscribers (Total fixed) per 100 & 18.5568352 \\
inhabitants & \\
Internet users per 100 inhabitants & 59.7161369 \\
Main (fixed) telephone lines per 100 & 16.3706894 \\
inhabitants & \\
Mobile cellular telephone subscribers per & 87.8635635 \\
100 inhabitants &.. \\
Personal computers per 100 inhabitants & 26571880 \\
Population & \\
\hline
\end{tabular}

In 1995, Malaysia was the first country in SouthEast Asia to allow public Internet access. The primary gateway, JaringNet, is one of the few in the world that allows users to select their domain names at that time. The following year saw the creation of the Multimedia Super Corridor (MSC), a brainchild of the then-Prime Minister Mahathir Mohamad. The MSC Malaysia is a Government initiative, designed to leapfrog Malaysia into the information and knowledge age. It originally included a concentrated area within the national capital, but since 2006, various cities in different states have been awarded the Cybercentre status so as to spread the benefits of ITC nation-wide.

Based on the figures from 2nd quarter of 2008, $59.75 \%$ of Malaysian citizens had access to the Internet at home, which translated to roughly 14.904 million. While about 1.718 million has broadband access and 3.8 million users are still using Dial-up connection.

\section{e-Government Status by Indicators}

\section{Management Optimization}

In the 8th Malaysian Plan (2000-2005), e-Government initiatives were included into the MSC (Multimedia Super Corridor) project and became one of the core initiatives to be undertaken. In addition, the Malaysian Public Sector ICT Strategic Plan was launched in 2003 by the government to ensure that the various ICT initiatives undertaken by the government agencies will be in line with the Public Sector ICT vision.

\section{National Portal}

In 2005, the new governmental Portal (www.gov.my) was launched. This is a single gateway for citizens, businesses and non-citizens to information and services provided by the Malaysian Government agencies on the Internet. Other than the usual form downloading, this portal allows users to do online payment, check for vacancies within the public sectors, bid for tender and many other interactive applications/services. Thus it was no surprise that MyGov portal won the Global ICT Excellence Award at the World Congress on Information Technology (WCIT) 2008.

\section{CIOs in Government}

All CIOs in the public sector are appointed based on a letter issued by the Chief Secretary General in 2000. As stipulated, CIO in public sector is responsible for planning, management, coordination and monitoring the ICT program of each department.

The Malaysian Administrative Modernization and Management Planning Unit (MAMPU) as the agency responsible as the Office of the Public Sector CIO, holds yearly conferences to provide exposure to all public sector CIO's regarding current development in the field of ICT. Since 2000, 4 conferences have been organized by MAMPU. 


\section{Required Interface}

Malaysia has enacted the Computer Crime Act in 1997 and is in the midst of enacting several new Cyber laws to protect its citizens. Among those in the pipeline are Electronic Government Activities Act, Electronic Transaction Act and Personal Data Protection Act.

In recent years, the government has implemented and deployed several transactional services, including eTender system and e-Tax system. Two-way interaction and processing services like e-Payment, Social Security and Labor Related Services too are being offered.

\section{E-Government Promotion}

The Malaysian Administrative Modernization and Management Planning Unit (MAMPU) has spearheaded the e-Government promotional activities within the country to create awareness and promote knowledge exposure towards numerous services offered by the Government to the citizen. Various road shows and exhibitions are conducted and positive feedbacks were collected from the public.

In the 2nd quarter of 2008, MAMPU published a journal called Bulletin MAMPU which aims to promote and disseminate current and useful ICT information to the Public Sector.

\section{Trends}

One of the main concerns is that even though the Internet usage among its citizens is almost $60 \%$, most of these users live in urban areas. The Malaysian Government does realize that there is still work to be done in providing rural folks with the infrastructure and the basic knowledge of ICT before they can be part of the beneficiaries of e-Government services.

With its aim to achieve the status of a developed country by 2020 , the Malaysian Government realized the importance of ICT in driving its efforts. Although it has achieved much in the last few years, the Malaysian Government continues to look for new technology and new initiatives to move it closer to its goal. In 2005, The Malaysian Information Communication and Multimedia Services (MyICMS) 886 Blueprint was introduced for the orderly integrated development of three converging technologies - cellular telephony, Internet and broadcasting. Malaysia's drive forward in the delivery of advanced information, communications and multimedia services from 2006 to 2010 can be fulfilled via this Blueprint.

\section{MEXICO}

\section{General Information}

Mexico is a country in North America with a population in 2007 estimated to be $108,700,891$. With total area $1,967,138$ square $\mathrm{km}$, Mexico has a population density of 53 people per square $\mathrm{km}$. It is the most populous Spanish-speaking country in the world.

Mexico is a federal constitutional republic, in which the Head of State and Government is held by President of the United Mexican States. Mexico comprises 31 states and a federal district. Mexican States is divided into municipalities governed by a mayor or municipal president. There are 2,438 municipalities in Mexico, in which 570 municipalities are in Oaxaca State.

Mexico is a new industrial country with Gross Domestic Product 1,022,816 million US dollars. in 2007 according to International Monetary Fund. Mexico government aims to promote the usage of Information Communication Technology in its country. As of year 2007, 21.4\% of its population has access to Internet. Among those Internet users, $4.27 \%$ users are using broadband network to access internet.

\begin{tabular}{lc}
\hline Series Name & 2007 \\
\hline $\begin{array}{l}\text { Internet subscribers (Total fixed broadband) } \\
\text { per 100 inhabitants }\end{array}$ & 4.269811153 \\
Internet subscribers (Total fixed) per 100 & 5.478541851 \\
inhabitants & \\
Internet users per 100 inhabitants & 21.41321182 \\
Main (fixed) telephone lines per 100 & 18.54261971 \\
inhabitants & \\
Mobile cellular telephone subscribers per & 64.06690216 \\
100 inhabitants &.. \\
Personal computers per 100 inhabitants & 106534880 \\
Population & \\
\hline
\end{tabular}

\section{e-Government Status by Indicators}

\section{Management Optimization}

Mexico has National Development Plan and eMexico System as strategies to promote e-government in the country. UGEPTI (Unidad de Gobierno Electrónico y Política de Tecnologías de la Información) under Secretaría de la Función Pública (SFP) has responsibility of implementing e-Mexico which includes education, health, business, and governmental services. EGovernment or Digital Government is one of strategies to achieve good government agenda, in which aimed the availability of government information and services for its citizens from home or office. It also encourages the condition of more services and better services for citizen trough the use of ICT. 


\section{National Portal}

Mexico Government Portal (http://www.gob.mx) as citizen portal organizes information by topic which is related to citizens' daily life. This portal also gives guidance for federal government services. Moreover, it integrates links to services of state and municipal governments. There is tool for citizens' participation and also provide mobile access services to the portal.

\section{CIOs in Government}

Mexico Government appointed Head of UGEPTI who has responsibility of conducting e-government at federal government. In each ministry, it also has Head of IT. However there is no law for defining role and function of $\mathrm{CIO}$ in government.

\section{Required Interface}

On May 29, 2000 the Mexican Government published several modifications to the Civil Code, the Civil Procedures Code, the Commerce Code and the Consumer Protection Law in order to properly protect any kind of electronic transaction. On January 2002, Mexico Government launched Tramitanet Portal (http://www.tramitanet.gob.mx) where citizens can access approximately 2,064 federal and state forms and electronic form. This portal gives transactional function for e-Payment (electricity bill) and Civil Registration Service, while other services support citizens to download form or submit form via portal.

\section{e-Government Promotion}

Mexico has laws, plans, policies and strategies in e-Government at the national level. To promote the e-Mexico program, the Federal Government collaborated with municipalities in establishing Digital Community Centers which gives access for citizen to internet and government digital services. Mexico has an e-Government fund in the form of the e-Mexico Trust Fund to support e-government program.

\section{Trends}

Starting with the National development Program (2001-2006), Mexico implemented the e-Mexico program and the Agenda of Good Government that are linked to the development of e-Government and the efficient use of TI. Mexico's Citizen Portal has linked services from public, private and social sectors, has citizen participation tools and provides content that make it easier for citizen to access based on themes and live events. It has won the UN Public Service Award in 2005. The Mexican government established more online services for its citizen like e-petitioning, digital medical file and public information. It also built more Digital Community Centers to connect all municipalities through the e-Mexico National System.

\section{NETHERLANDS}

\section{General Information}

The Netherlands is located in Western Europe and has a population of $16,645,313$. Its total land area is about 41,864 square kilometers. The Netherlands is a constitutional monarchy. The Monarch appoints the Prime Minister, who then chooses the members of the Council of Ministers or the Cabinet. The Council of Ministers plans and implements the government policy.

The per capita GDP is estimated to be around $\$ 39,000$ (as of 2007). The Netherlands has a prosperous and open economy, which depends heavily on foreign trade. The economy is noted for stable industrial relations, moderate unemployment and inflation, a sizable current account surplus, and an important role as a European transportation hub. Industrial activity is predominantly in food processing, chemicals, petroleum refining, and electrical machinery. ${ }^{19}$

As of March 2008, that Netherlands had approximately $15,000,000$ Internet users or a $90.1 \%$ penetration rate. Among those Internet users, around $5,470,000$ are broadband subscribers ( 13.8 penetration rate). ${ }^{20}$

\begin{tabular}{lc}
\hline Series Name & 2007 \\
\hline Internet subscribers (Total fixed broadband) & 33.54077 \\
per 100 inhabitants &.. \\
Internet subscribers (Total fixed) per 100 & \\
inhabitants & 91.35854 \\
Internet users per 100 inhabitants & 44.66879 \\
Main (fixed) telephone lines per 100 & \\
inhabitants &.. \\
Mobile cellular telephone subscribers per 100 &.. \\
inhabitants & 16418826 \\
Personal computers per 100 inhabitants & \\
Population & \\
\hline
\end{tabular}

The number of mobile phone subscribers in the Netherlands is estimated to be around 17.3 million (as of Dec. 2007).

\footnotetext{
${ }^{19}$ https://www.cia.gov/library/publications/the-world-factbook/ geos/nl.html.

${ }^{20} \mathrm{http}: / /$ www.internetworldstats.com $\backslash$ europa.htm\#nl.
} 


\section{e-Government Status by Indicators}

\section{Management Optimization}

The Dutch e-Government policy is focused on the effective use of ICT to improve the standard of service to the business community and the general public. It is aimed at reducing the burden of citizens and businesses by offering online services and reuse of information. The Dutch eGovernment policy is a key component of the Cabinet Policy Programme "Working Together, Living Together".

The Ministry of the Interior and Kingdom Relations created the ICT Unit (ICTU) to handle implementation and coordination of eGovernment projects and policies. The Dutch government has its own intranet called "RYX". It connects 14 ministries and provides broadband access for faster information sharing and data access.

\section{National Portal}

The national e-Government portal provides citizens, businesses and Public Administrations with an easy and convenient access to an increasing amount of information and services. It provides access to collections of rules, regulation, licenses and public announcements.

The portal has relatively efficient navigation system but lacks some of the features for sharing views, online discussion and public forums. It has no podcasting feature but it has an RSS function for receiving updates from the site.

\section{CIOs in Government}

There is no specific law or mandate creating the CIO position in Netherlands. However, they have appointed the state secretary of the Interior and Kingdom Relations as being responsible for the coordination of eGovernment policy in Netherlands.

Meanwhile, the ICT Unit (ICTU) handles the implementation of the eGovernment projects together with the Association of The Netherlands Municipalities and provinces to support them in realizing their part in electronic Government: EGEM (Electronic Municipalities) and e-Provinces (Electronic Provinces). As a result of the common declaration, implementation teams have been created in order to support municipalities with designing and implementation plan, to realize the eGovernment basic provisions in the municipalities.

\section{Required Interface}

The government has 20 basic public services offered online for their citizens and businesses. Most of them have varying levels of sophistication. They have not yet implemented an e-Tender system but they have an electronic system for filing of taxes. For social security services and labor-related services, the government offers a transactional site for the citizens to process their applications.

As f Cyber Laws, the government has adopted some legislation to support the development of e-Government services in the country. These include the Government Information Act (1991), Personal Data Protection Act (2000), eCommerce Act (2004), Telecommunications Act (2004) and the Electronic Signature Act (2003).

\section{e-Government Promotion}

There is currently no overall eGovernment legislation in the Netherlands. Specific legislation is under preparation concerning certain eGovernment building blocks, e.g. the Citizen Service Number, the key registers on Natural Persons, Companies, and Plots, and the eNIK electronic Identity card.

An e-Government planning review has been developed to safeguard the cohesion of the key services and to clarify for organizations when they can connect to these services. In order to be able to ensure cohesion, as well as give organizations direction for their own activities, the Ministry of the Interior and Kingdom Relations monitors the results of the government's electronic services.

\section{Trends}

The Dutch Government aims to take advantage of the opportunities offered by ICT to improve the standard of service to their citizens. The government envisioned to provide better work with less people. A large part of the administrative reduction comes within range by effective use of ICT, e.g by offering online services and reuse of information. They have developed better ICT infrastructure for seamless exchange of data and information.

In January 2005, the Dutch Digital Identity service DigiD is launched. DigiD provides citizens with a centralized online authentication solution for accessing eGovernment services, based on user ID and password. Accordingly, the Dutch Government's target of $60 \%$ of the public services processed electronically in 2006 
has been reached. Three quarters of the Dutch internet population has already used an electronic Government service.

\section{NORWAY}

\section{General Information}

The Kingdom of Norway is located in northern Europe. It covers an area of $323,758 \mathrm{~km}^{2}$ with a population of 4,681,100. The capital, Oslo, is located in southeastern part of the country. Norway is a parliamentary democracy under a constitutional monarchy. The monarch is King Haraold V and the prime minister is Jens Stoltenberg. The official language of Norway is Norwegian (Bokmâl and Nynorsk) and in some districts, Sámi is also an official language. The national currency is Norwegian krone. The national GDP is around NOK 2,276 billion (EUR 280.4 billion) in 2007 with NOK483, 725 (EUR 59,597) GDP per capita.

According to Statistics Norway, $82 \%$ of households had access to $\mathrm{PC}$ and $78 \%$ had access to the Internet in 2007. Moreover, 2 of out of 3 households (67 percent) have broadband Internet access. Although the share of household in Norway with access to a PC and the Internet is about the same as in other Nordic countries, Norwegian enterprises use ICT to a lesser extent than enterprises in the neighboring countries.

\begin{tabular}{lc}
\hline Series Name & 2007 \\
\hline Internet subscribers (Total fixed broadband) & 30.56676 \\
per 100 inhabitants & \\
Internet subscribers (Total fixed) per 100 & 34.10996 \\
inhabitants & \\
Internet users per 100 inhabitants & 80.88381 \\
Main (fixed) telephone lines per 100 & 42.31181 \\
inhabitants & \\
Mobile cellular telephone subscribers per & 110.5036 \\
100 inhabitants &.. \\
Personal computers per 100 inhabitants & 4698097 \\
Population & \\
\hline
\end{tabular}

\section{e-Government Status by Indicators}

\section{Management Optimization}

Norway has sufficient network infrastructure to connect among individual users, government agencies, and enterprises. In 2007, up to $55 \%$ of individual users and $65 \%$ of enterprises uses Internet to obtain information from the public authorities.
Norway has an operative plan, eNorway plan, that helps define the current ICT situation, what has to be done, who is responsible and when the actions are to be implemented. Under the eNorway plan, there are several action plans with specific deadline and assigned actors. The eNorway plan is revised every 6 months and the progress is reported to the Prime Minister monthly. In 2006, eNorway adopted a new strategy, "An Information Society for All". The strategy has two main focuses: digital inclusion and round-the-clock electronic public administration services. Moreover, Ehandel.no contains strategy and actions for the use of electronic business processes and electronic procurement in the public sector.

\section{National Portal}

Norway's national portal, government.no, provides easy navigation functions to optimize user's browsing experience. The portal is presented in an organized manner with clear location indicators in its main page and sub-pages. The site also provides search engines for users to easily find desired information. Moreover, the portal contains information about the structure of the government to provide users with a better understanding about the Norwegian government. The portal also provides specific contact information and allows users to search for individual employees' contact information using a search engine.

The national portal has multi-language function to allow users to view the site in Bokmâl, Nynorsk, Sámi, and English. Furthermore, the site provides users with functions to enlarge the font of the site or listen to the site.

\section{CIOs in Government}

Although there is no specific reference to CIOs in the government, there are individuals assigned as "Minister responsible for e-Government", and "Head of eGovernment".

\section{Required Interface}

Norway has several required interface functioning applications available. Norway has the Electronic Communications Act, Electronic Commerce Act, and the Domain Regulation to regulate Internet activities to make it as safe as possible. Norway also has e-payment for citizens to easily make transactions over the Internet. Moreover, there is currently a working committee appointed by the Ministry of Local Government and Regional Development to give recommendations on the future of electronic elections in Norway. 


\section{e-Government Promotion}

e-Government implementation is an important mission for the government. "An Information Society for All" plan is the main strategic plan to bring electronic public administrative services to the citizens. As mentioned before, the Prime Minister is directly involved in monitoring the its progress.

\section{Trends}

Norway has a relatively complete physical network structure in place for the integration of e-Government. Currently, the national portal proves to be useful for users to retrieve information, download forms, and contact the government. In 2006, the new "An Information Society for All" strategy, integrated the previous e-Norway strategy and also provides a clearer direction as to how the strategies will be taken into actions and how the opportunities of eServices can be realized in the years to come.

\section{NEW ZEALAND}

\section{General Information}

New Zealand is located in the South Pacific Ocean and has a population of about 4 million with GDP per capita of about US\$26,000. (IMF, 2007). The land area of NZ is about 268,000 square $\mathrm{km}$. There are 22.5 broadband internet subscribers per 100 persons. There are 54.19 Internet users per 100 people (ITU). There 60.36 computers per 100 people (ITU, 2003). NZ is a parliamentary democracy and a constitutional monarchy. The head of state of NZ is the Queen of England represented by a Government General. Actual political power is held by a Prime Minister.

New Zealand has two layers of government; the national government and local council government.

\begin{tabular}{lc}
\hline Series Name & 2007 \\
\hline $\begin{array}{l}\text { Internet subscribers (Total fixed broadband) } \\
\text { per 100 inhabitants }\end{array}$ & 22.49599 \\
Internet subscribers (Total fixed) per 100 & 35.04348 \\
inhabitants & \\
Internet users per 100 inhabitants & 80.41119 \\
Main (fixed) telephone lines per 100 inhabitants & 40.82782 \\
Mobile cellular telephone subscribers per 100 & 101.5909 \\
inhabitants &.. \\
Personal computers per 100 inhabitants & 4178523 \\
Population &
\end{tabular}

\section{E-Government Status by Indicators}

\section{Management Optimization}

In 2000, an e-Government Unit was formed to coordinate e-Government activities based on the following principles that namely; e-Government development would take a "... graduated approach ..."; development would utilize “... cross government collaboration ..." and technology would only be used as a tool as opposed to being "an end in itself". In 2001 the e-Government Unit produced New Zealand's first eGovernment strategy which was to put Government services online.

The Strategy was updated in 2003 and again in 2006. The development of the 2006 Strategy is on the basis that many Government services are already online. The focus of the 2006 Strategy is "Enabling Transformation - Making Government Work for You" and is set to run to 2010 .

Of particular note is the Victoria University, School of Government, which has a Professor of e-Government studies. This is a post recently established in 2007.

\section{National Portal}

The National Portal has the web address http:// newzealand.govt.nz/. It has a comprehensive listing of links to government agencies and ministries throughout New Zealand.

\section{CIOs in Government}

The NZ Government has at least one CIO at every level of Government. A National CIO has only been formally given the title of "CIO" in 2008. Several New Zealand Universities offer CIO related courses such as Business Management and Information Systems qualifications.

There are non Government bodies providing training and exchange of ideas on issues facing CIOs.

\section{Required Interface}

The Government has numerous e-Government services which include; e-Tender Systems, e-Payment, Social Security Systems, Civil Registration Systems, Consular Systems and Labor Related Systems. Recently New Zealand launched its iGovernment service which enables users to provide their personal details online securely. As part of the iGovernment service, users are also able through the same single point of entry to identify themselves to multiple Government ministries. 


\section{e-Government Promotion}

The main body in New Zealand promoting eGovernment is the e-Government Unit which is headed by the NZ Government Chief Information Officer. This Unit is located inside the ministry of State Services. There is no specific legislation for e-government but there is legislation which supports the development of e-Government such as the Electronic Transaction Act of 2002 and the Unsolicited Electronic Messages Act of 2007.

The government promotes collaboration across government and the New Zealand CIO works together with heads of ministries and agencies. This helps to ensure buy-in of e-government projects. Surveys are done of citizens and ministries to gauge the demand and acceptance of e-Government.

\section{Trends}

The Government is looking at e-Government as a way to transform not only how public services are delivered, but also with a view to transforming the efficiency of the Government itself. Hence the latest strategic theme of "Transformational Government."

\section{PERU}

\section{General Information}

Peru is the third largest country in South America with an area of 1,285,216 square kilometers and holds sway over the sea (Pacific Ocean) up to 200 miles from its Coast. Its population is 27 million inhabitants (Urban: $72.3 \%$; Rural: $27.7 \%$ ), according to the 2007 census. The country's GDP per capita (based on Purchasing Power Parity) is USD 7802.93. (Inter-American Development Bank, http://www.iadb.org/gl/).

Peru has a democratic governmental system. The President and the Congress are elected every five years. The country is divided into Regions, headed by Regional Presidents. The country's general policies are formulated by the Executive branch and the Legislative branch with a nationwide scope.

Related to Internet access, according to the Peruvian Regulator for Telecommunications (OSIPTEL) the main access technology is ADSL, with 565,007 subscribers (December 2007). Among them, public access centers account for 52,223 subscribers. Given the reduced income of a significant group of Peruvians, public access centers (Internet Booths) are the main way of accessing the Internet in the country.

As for Internet access through mobile terminals, there are 5,508,518 subscribers (excluding WAP technology or services provided over $2.5 \mathrm{G}$ or $3 \mathrm{G}$ technologies) as of December 2007.

\begin{tabular}{lc}
\hline Series Name & 2007 \\
\hline Internet subscribers (Total fixed broadband) & 2.04359 \\
per 100 inhabitants &.. \\
Internet subscribers (Total fixed) per 100 & \\
inhabitants & 27.36774 \\
Internet users per 100 inhabitants & 9.580959 \\
Main (fixed) telephone lines per 100 & \\
inhabitants & 55.25348 \\
Mobile cellular telephone subscribers per 100 & \\
inhabitants &.. \\
Personal computers per 100 inhabitants & 27902760 \\
Population &
\end{tabular}

\section{e-Government Status by Indicators}

\section{Management Optimization}

The National Plan for the Development of the Information Society (the Plan) was formulated in 2006. That same year the government approved the National E-Government Strategy (the Strategy).

With this Strategy, Peru seeks reform its public sector by through the use of ICT, integrating the information systems inside their governmental offices in order provide convenient services to the citizenry.

The Strategy encompasses all levels of government and it has defined targets as well as follow-up mechanisms.

The agency in charge is the National Office for Electronic Government and Informatics (ONGEI), which reports to the Presidency of the Council of Ministers.

There is a plan to integrate governmental systems and there are already a Financial Management Integrated System http://www.mef.gob.pe/siaf/default.html and a Human Resources System.

\section{National Portal}

There is a National Homepage (http://www.peru. gob.pe) and an e-services portal (http://www.servicios alciudadano.gob.pe/). These two pages can be considered "information portals", as they link to the specific web pages were e-services and transactions are provided. Information in English is available mainly for tourism purposes. 


\section{CIOs in Government}

The CIO position does not exist in the current legal framework. In any case, its functions could be assigned to the Chief of the National Office for Electronic Government and Informatics (ONGEI).

\section{Required Interface}

There is a Law concerning the usage of Digital Signatures in the Public Administration but its provisions are still being implemented. E-Tender systems, as well as e-Tax and e-Payment systems are available for certain government offices. Civil Registration services provide mainly information on the available procedures. As for consular services, the usage of ICT depends on the embassy or consulate. For instance, the Consulate General in Tokyo (www.consuladoperutokio) allows users to download forms, request information on the status of applications and its web page has a chat section (available on a designated weekday and time).

\section{E-Government Promotion}

Peru is currently in the early stages of having an integrated electronic government. The approach so far has been an agency-based one: single governmental agencies working by themselves. Ongoing electronic government implementation plans consider grants from international development banks, as well as developed countries' support (know-how).

\section{Trends}

Peru has started working on an integrated Strategy. Main targets include improving the usage of eGovernment services (among those who already have ICT availability) while providing services to those majorities living in rural areas or with low incomes.

With the integration of governmental services will provide citizens with convenient and better services, in a secure transaction environment (e.g. the initiative for starting a business by establishing a company in 72 hours).

\section{PHILIPPINES}

\section{General Information}

The Republic of the Philippines is an archipelagic country composed of more than 7000 islands over an area of 299,764 square kilometers. The population was projected to be around 88.7 Million in 2007. The country has a relatively high literacy rate which is reflected in the use of English as one of its official languages together with its native language called Filipino. It has a very centralized government where most of the government services are provided by the national government. While the government is still highly centralized, there is movement towards towards more decentralization. This shift is influencing the e-Government strategy that the Philippines adopted.

\begin{tabular}{lc}
\hline Series Name & 2007 \\
\hline $\begin{array}{l}\text { Internet subscribers (Total fixed broadband) } \\
\text { per 100 inhabitants }\end{array}$ & 1.099999 \\
Internet subscribers (Total fixed) per 100 &.. \\
inhabitants & \\
Internet users per 100 inhabitants & 6.025458 \\
Main (fixed) telephone lines per 100 inhabitants &.. \\
Mobile cellular telephone subscribers per 100 & 58.88464 \\
inhabitants & \\
Personal computers per 100 inhabitants &.. \\
Population & 87960112 \\
\hline
\end{tabular}

\section{e-Government Status by Indicators}

\section{Management Optimization}

As a developing country, the Philippines is still focused mostly in building its infrastructure. One such infrastructure that is still being planned is the establishment of a National Broadband Network that will supposedly serve as the national backbone to connect all national government offices and local governments. This base infrastructure is planned to be in place by 2010 as indicated as one of the targets for the National ICT Roadmap. As such other optimization initiatives has to wait before it can be implemented, though limited implementations in some national government offices has been accomplished such as the establishment of a centralized procurement platform.

\section{National Portal}

The Philippine portal at www.gov.ph is integrated for access to information and transactions with the Philippine Government. It contains links to various services 
for sectors of the Philippines such as citizens, government employees and businesses. While the site provides common and basic information it lacks the sophistication of more advanced government portals and is suited towards users who have limited connectivity. This design philosophy might be linked to the quality of internet access where broadband connectivity is still concentrated on the urban areas and dial up internet is still pervasive in much of the countryside. With limited connectivity there is not much demand as of the moment for a more sophisticated portal. But this is expected to change as broadband infrastructure is built up and the number of more sophisticated internet users increase. Also with an estimated 60 Million mobile user base and the growing popularity of mobile internet, demand for access thru this access mechanism will have to be in place. It is expected that in the near future the portal will be redesigned to accommodate mobile internet access.

\section{CIOs in Government}

In recent years there are CIOs appointed at the different levels of government, a reflection of the government's acknowledgement of its importance in the bureaucracy, there is still no official mandate and clear definitions of its functions in government. This lack of official framework has been, to a certain extent, mitigated by the presence of CIO support mechanisms like the establishment of a CIO organization namely the CIO Forum. Also the lack of the legal infrastructure for CIO positions in government is being addressed by the Department of ICT Bill pending in the Philippine Congress. The House of Representatives already passed the bill in June 2008 and is awaiting passage of its counterpart bill in the Senate where it is expected to be passed and signed into law soon. This law would then institutionalize the role of CIO in government.

\section{Required Interface}

Over the last five years the government has actively implemented and improved systems considered key interfaces for e-Government. One recent milestone is the implementation of the electronic payments portal which would allow government agencies to accept electronic payments. It is expected that with the availability of such mechanisms, more online services will be made more transactional instead of just downloading and uploading of files.

\section{e-Government Promotion}

The Philippines has initiated various projects to promote e-Government, and created funding through the e-Government Fund administered by the Commission on ICT. While there has been relative success in promoting e-Government at the national level, there is still a need to increase the awareness of e-Government at the sub-national level. It must be noted though that various local governments have initiated in their jurisdictions e-government projects but these local governments are currently more of a minority than a majority.

\section{Trends}

Over the last 5 years, significant growth in internet users, and the improvement of the digital infrastructure resulted in higher imperative for online services though e-government initiatives. This is palpable in the availability of core government services. It has been noticed though that focus has been on the development of infrastructure and systems. This it seems results from the limited resources available for e-government as more pressing concerns such as poverty is also affecting the country. The government has also recognized the importance of ICT and is working on legislation that will improve the legal and support structures for the development of ICT and e-Government in the Philippines. It is believed that this legislation will be continue to enhance the prospects of e-Government in the Philippines.

\section{RUSSIAN FEDERATION}

\section{General Information}

The Russian Federation is a transcontinental country extending over much of northern Eurasia. Russia is the largest country in the world, covering more than an eighth of the Earth's land area; with 142 million people, it is the ninth largest by population. It is a semipresidential republic comprising 83 federal subjects.

The country with such a large territory has still underdeveloped telecommunication infrastructure and rather low level of Internet penetration. It constitutes around $25 \%$ of the country's population. The country is nonhomogeneous according to the level of ICT utilization. High level of "digital inequality" of the regions is a specific feature of Russia in regard to the development of e-Government. 


\begin{tabular}{lc}
\hline Series Name & 2007 \\
\hline $\begin{array}{l}\text { Internet subscribers (Total fixed broadband) } \\
\text { per 100 inhabitants }\end{array}$ & 2.807046413 \\
Internet subscribers (Total fixed) per 100 & 21.40372849 \\
inhabitants & \\
Internet users per 100 inhabitants & 21.05284882 \\
Main (fixed) telephone lines per 100 & 31.01786232 \\
inhabitants & \\
Mobile cellular telephone subscribers per & 114.5976715 \\
100 inhabitants &.. \\
Personal computers per 100 inhabitants & 142498528 \\
Population & \\
\hline
\end{tabular}

\section{e-Government Status by Indicators}

\section{Management Optimization}

Russia's e-Government strategy has been implemented under the federal development program "Electronic Russia 2002-2010" The first objective of establishing e-government was focused on the creation a single information space for Government and its agencies. Therefore, most of large scale projects were carried out by the federal ministries. The funds received by Federal Agencies' for introducing ICT constituted more than $80 \%$ of the total IT-expenditures of the Federal Government.

The implementation of e-Government from the very beginning has suffered a lack of coordination. It was managed independently by several federal agencies and resulted in partial duplication in the projects carried out by different agencies and incompatibility or even contradiction of information systems developed at the regional level. Thus, autonomous ministerial subsystems have been created instead of a single information system.

In August 16, 2007 the new concept of electronic government 2007-2011 has been accepted. It assumes 2 stages of e-government implementation: (1) 2008 development of documentation; (2) 2009-2010 implementation

\section{National Portal}

The government portal 'government.ru' provides citizens with basic information about the Government activities and the structure of executive authorities with links to respective websites. At the same time there are no services provided to the people via this portal, except for "mail me" service. The portal is available only in Russian, while only press releases on government meetings are provided in English. The portal has a mobile phone version, but lacks some basic functions such as webmaster email, information about browsers and operating system, and many advanced features such as multimedia shows, sharing, tagging, blog, podcasts etc.

\section{CIOs in Government}

Russia does not have CIOs appointed at any government level. However, there are a number of CIO related courses and programs offered at different universities across the country. There are a number CIO related organizations both country wide and regional. A lot of national and foreign companies are providing IT management consultancy.

\section{Required Interface}

The current legislative basis for e-Government transactions is comprised by the Federal law on information, informatization and information security (February 20, 1995, amended 2003) and the Federal law on electronic digital signature (10 January 2002) The legislation is still needed to be adjusted to new realities of communication between governmental agencies and the society at large.

Because efforts of the Government have been mostly focused on informational presence at the Web, there are only few services provided to the people via Internet by governmental agencies, such as e-Tax and e-Tender.

\section{e-Government Promotion}

To encourage the regional authorities to introduce ICT for improving governance in regard to its transparency, accountability and responsiveness the Federal government has provided several IT projects competitions.

Implementation of e-Government in regions has been implemented under the Regional Informatization concept accepted in 2006. The Concept sets forth the priorities, principles and approaches of accomplishment of the unified state policy in the field of regional informatization in accordance with the concept of modernization of the public administration and socio-economic development of country regions.

The funds for ICT development and e-Government implementation were budgeted under the federal program "e-Russia".

Moreover, government and academic institutions were organizing conferences, seminars and conducting research on e-Government in Russia. 


\section{Trends}

Russia has been working on e-Government implementation since 2002.

The implementation of e-Government from the very beginning has suffered from a lack of clear state policy in ICT, clear formulation of the principles for eGovernment implementation, interrelation between eGovernment, with administrative, political, social and economic reforms, lack of coordination in local, regional, and national e-Government initiatives.

As was confirmed by government officials, there were no substantial achievements in improving the quality of governance with the help of ICT either at regional or municipal level even in the regions with advanced level of ICT development. Therefore the Government has approved a new conception of electronic government in Russia 2007-2011 which is aimed to address the previous shortcomings.

\section{SINGAPORE}

\section{General Information}

With a population of less than 5 million and occupying $707.1 \mathrm{~km} 2$, Singapore is the smallest nation within Southeast Asia and one of the four remaining true city-states in the world. Singapore is a parliamentary democracy with a Westminister system of unicameral parliamentary government representing different constituencies. As such, the bulk of the executive powers rest with the Cabinet, headed by the Prime Minister. A former British colony that was momentarily a part of the Federation of Malaysia, Singapore has grown from strength to strength in the last 44 years and has managed to reach a GDP per capita of USD\$35,163 (as of 2007 ) in the same period of time.

From the first IT plan launched in 1980 (National Computerization Plan) to the latest 10-year master plan (iN2015) launched 3 years ago, the Singapore Government was among of the first to realize the potential of ICT and the benefits it would bring to the public administration. It was thus not a surprise that in 1995, Singapore became one of the first few Asian countries to launch its government website. The Singapore Government adopted the stance that its citizens are its customers and the number one priority for any government is to please its customers.

Based on the figures taken from Infocomm Usage in Households and Individuals 2007 Survey conducted by Infocomm Development Authority of Singapore (IDA),
$74 \%$ of households in the country have access to the Internet at home with almost $95 \%$ of them using broadband to connect to the Internet. In the same survey, it was found that $15 \%$ of the Internet users aged 15 years and above uses the Internet to deal with government organizations/public authorities.

\begin{tabular}{lc}
\hline Series Name & 2007 \\
\hline Internet subscribers (Total fixed broadband) & 19.86573029 \\
per 100 inhabitants & \\
Internet subscribers (Total fixed) per 100 & 43.69198227 \\
inhabitants & 69.98876953 \\
Internet users per 100 inhabitants & 41.91121292 \\
Main (fixed) telephone lines per 100 & \\
inhabitants & 126.6645966 \\
Mobile cellular telephone subscribers per &.. \\
100 inhabitants & 4436283 \\
Personal computers per 100 inhabitants & \\
Population & \\
\hline
\end{tabular}

\section{e-Government Status by Indicators}

\section{Management Optimization}

From the first e-Government Action Plan (2000 to 2003) to the second e-Government Action Plan II (eGAP II), unveiled in July 2003, the Singapore Government had achieved its target of further spurring the transformation of the public service into a Networked Government that delivers accessible, integrated and value-added e-services to its customers, and helps bring citizens closer together.

The latest Government Infocomm Plan by the Singapore Government, the iGov2010 (2005 to 2010), was developed in consultation with its people, the private and public sectors. The iGov2010 vision is to be an Integrated Government (iGov) that intelligently addresses customer's needs and delivers quality services that delight them.

\section{National Portal}

After the initial launch of the Singapore Government website, it underwent several revamps. In 1999, it began its drive to become a one-stop Government eservice portal with over 330 e-services available. Then in 2001, it adopted the brand name "SINGOV". Later in 2004, SINGOV was repositioned as part of Singapore Government Online for better integration with other major government gateways such as eCitizen and Business Town.

Now, the portal (www.gov.sg) provides over 1,600 feasible e-services online for its citizens and online visitors alike. $86 \%$ of those who transacted through the portal did so at least once electronically with $85 \%$ satisfaction rate. 


\section{CIOs in Government}

The Government Chief Information Office (GCIO) wing was set up in 1996 to plan and oversee the development and integration of civil service-wide IT applications. Today the GCIO is part of the Infocomm Development Authority of Singapore (IDA). The IDAGCIO provides technical advice, master-planning and project management services to MOF (Ministry of Finance), who is the e-Government Owner, and government agencies. In addition, IDA-GCIO also identifies and conceptualizes e-Government program and projects, and finally it also drives the development and implementation of e-Government programs and projects.

\section{Required Interface}

In 1998, the Singapore Government enacted 2 important laws to provide protections to its citizens in the cyber world, namely The Electronic Transaction Act 1998 and the Computer Misuse (Amendment) Bill 1998. A year before, the Evidence Act (Cap 97) was also amended to allow the use of electronic records as evidence in the courts. Following similar laws in US, Japan, South Korea and Australia, the Spam Control Act came into effect last year offering a framework to better manage unsolicited commercial electronic messages sent in bulk.

Almost $98 \%$ of Singapore public services are available online with the majority of them being transactional in nature. Citizens of Singapore are able to almost do everything online, from filing and paying their taxes, to managing their pensions and mortgages, to registering their marriage, newborn or the death of their loved ones over the Net. While businesses in Singapore can bid for Government tender online, apply or renew their licenses or permits, and even check and file for their patents, trademarks and/or IP online.

\section{e-Government Promotion}

The Singapore Government has created awareness and increased the usage of online services through various road shows and promotional events. It had also offered a variety of incentives to encourage its citizens and businesses into using these services. Thus it was no surprise that in a 2007 e-Government Perception Survey, conducted by the IDA, eight out of 10 individual users and businesses indicated that they were satisfied with the overall quality of government e-services.
In addition, the Infocomm Development Authority of Singapore (IDA) has launched a fellowship program for ASEAN countries in the areas of e-Government and telecom regulation in 2007. IDA together with the Institute of Systems Science (ISS) and the Lee Kuan Yew School of Public Policy (LKY SPP), both of the National University of Singapore, are the three partner institutions behind the Singapore e-Government Leadership Centre (eGL) with the aim of sharing the knowledge and lessons learnt in the Singapore e-Government and building on the intellectual capital of e-Government leaderships of the participants, both local and foreign.

\section{Trends}

Singapore has advanced considerably since implementing its first e-Government Plan in the early 80s. The Civil Service Computerization Program (19801999) automated work functions and reduced paperwork for greater internal operational efficiencies. The next two Action Plans that followed - the eGAP (20002003) and eGAP II (2003-2006), rolled out as many public services online as possible with the emphasize of improving the service experience of its customers. By 2006, an e-lifestyle has become more prevalent in Singapore. Both individuals and businesses transact online with a breeze. Singapore citizens readily give feedback and participate actively in the policy review process through electronic consultations and virtual communities. While the business communities have benefitted from the reduction of paperwork and red tape through these online services.

Moving forward with its latest National IT Plan, the iN2015 (2005 to 2015), the Singapore Government envisions a future where Singapore will be "An Intelligent Nation, A Global City, Powered by Infocomm", propelled by three "I"s - Innovation, Integration and Internationalization. With its impressive track record so far, this little island seemed very much on track in achieving yet its goal to be the best with regards to ICT.

\section{SOUTH AFRICA}

\section{General Information}

South Africa is located at the southern part of Africa as has been independent since 1910 and currently has 11 official languages. As of 2008, South Africa had a population estimated of 47,900,000 with GDP per capita income of $\$ 9,767$, ranking seventh in Africa. 
In 2007, South Africa faced lack of capacity in electronic generating and reticulation infrastructure, because of this, the country suffers from blackouts in countryside areas and businesses and consumers are not able to meet daily demands.

\begin{tabular}{lc}
\hline Series Name & 2007 \\
\hline $\begin{array}{l}\text { Internet subscribers (Total fixed broadband) } \\
\text { per 100 inhabitants }\end{array}$ &.. \\
Internet subscribers (Total fixed) per 100 &.. \\
inhabitants & 8.16439724 \\
Internet users per 100 inhabitants & 9.556009293 \\
Main (fixed) telephone lines per 100 & \\
inhabitants & 87.07866669 \\
Mobile cellular telephone subscribers per & \\
100 inhabitants &.. \\
Personal computers per 100 inhabitants & 48576764 \\
Population & \\
\hline
\end{tabular}

\section{e-Government Status by Indicators}

\section{Management Optimization}

In 2002, South Africa established the act of Electronic Communications and Transactions Act to provide and regulate electronic communications and transactions as their national e-strategy. This act also prevents the abuse of usage of the information system, yet encourages the use of e-Government services. In 2008, the country is aiming to achieve its "e-government Service Delivery Projects". Under this plan, the country intends to implement Home Affairs service to reduce ID process turnaround time. The government is also expecting implementation in six e-services scoping documents in place and validating the framework by December 2008. Lastly, South Africa has implemented ID Smart Cards in June 2008.

\section{National Portal}

South Africa has a clear government official website, which links to services for people, organizations, and foreign nationals, and government information. The website contains more documentation than online services. The website is in ten different languages due to the diverse cultures in South Africa. The site links to different departments, documents, news and information about the country. The site could be improved by adding sharing tag function, font change capability and background color change.

\section{CIOs in Government}

The role of CIO in South Africa was endorsed by The Government IT Officer's (GITO) council in 2002.
GITO was created to serve as an IT coordinator and consolidating in government agencies. The council functions as a platform among government and citizens ensure that the government is aware of the needs of citizens. CIO was appointed to certain effective implementation of IT strategies are planned within each province. GITO council monitors CIO to assure that improvements are progressing, new IT framework and strategies are implemented, establish IT policies and implementation in provinces.

South Africa also has CIO programs and courses in universities and government agencies to provide businesses and individuals to achieve their degree.

\section{Required Interface}

Compared to other countries, the country is still behind in e-Services; the country has established plans and strategies for implementing e-tax, e-voting, and labor related services.

\section{e-Government Promotion}

South Africa's concept of e-Government is to provide a better connection among citizens, central government, and local government. E-government services are implemented to offer citizens, businesses, employees, and other governmental agencies to locate and share information in a secured and trusted platform. The country has developed a Provincial Enterprise Architecture (PEA), which is a business-based framework and was adapted to transform the concept of one central government to citizen-oriented, result-oriented, and market-based framework. The purpose of this framework is to reduce redundancies in government's ICT investment and the government may integrate government activities using a standard approach when necessary.

In addition, South Africa has a public service agency called Batho Pele; its vision is to serve excellent service and commit to improve service deliveries to its citizens. E-government services are advertised in Batho Pele site to encourage citizens to be aware of the existence of online services provided by the government. Batho Pele organizes, plans, and develops new services to meet the needs of citizens and improve country's IT services. The government works closely with Batho Pele agency to develop and implement new services to assist the country to a "better-life-for all" to its people. 


\section{Trends}

South Africa still has many opportunities for improvement as there are not many online services currently available. The country has established plans and policies to aim to improve its online services. South Africa aims to provide more secured e-Services to its citizens and better connection among government and citizens.

\section{SPAIN}

\section{General Information}

Spain is a hereditary constitutional monarchy. Legislative power is held by a bicameral parliament comprising a Lower House (Congress of Deputies) and an Upper House (Senate). Spain adopted a highly decentralized system with 17 autonomous regions - known as 'Autonomous communities'. These communities elect their own parliaments, which nominate local governments.

The Head of State is the hereditary monarch, King Juan Carlos I (since 22 November 1975). The Head of Government is the Prime Minister. The land area of Spain is 504,842 square kilometer while the population is 40,491,051 in 2008. The GDP is 1,049,848.0 million euro (2007).

Sixty three percent of the population has Internet access (2008) and among them, 39\% of households and $90 \%$ of enterprises has a broadband connection. Percentage of individuals using the Internet for interacting with public authorities: obtaining information $25.1 \%$, downloading forms $14.2 \%$, returning filled forms $8.4 \%$ (2007). Percentage of enterprises using the Internet for interacting with public authorities: obtaining information $53 \%$, downloading forms $53 \%$, returning filled forms 38\% (2007).

\begin{tabular}{lc}
\hline Series Name & 2007 \\
\hline $\begin{array}{l}\text { Internet subscribers (Total fixed broadband) } \\
\text { per 100 inhabitants }\end{array}$ & 17.94227219 \\
Internet subscribers (Total fixed) per 100 & 18.63506126 \\
inhabitants & \\
Internet users per 100 inhabitants & 44.46784973 \\
Main (fixed) telephone lines per 100 & 41.96845245 \\
inhabitants & \\
Mobile cellular telephone subscribers per & 110.2391205 \\
100 inhabitants &.. \\
Personal computers per 100 inhabitants & 44279184 \\
Population & \\
\hline
\end{tabular}

\section{e-Government Status by Indicators}

\section{Management Optimization}

E-Government started in 1999 with the approval of the "Info XXI initiative for the development of the Information Society" in 1999. The next action plan is The "Info XXI action plan 2001-2003" in 2001. The plan focused on promoting the ICT sector, the development of Electronic Administration and the access to the Information Society for everyone.

From 2004-2007, the government implemented the 'Public Administration Technological Modernization Plan 2004-2007' (the 'Plan Conecta'). The plan aims to help modernize public administration on the basis of e-Government, process redesign, inter-administrative coordination and cooperation, multi-channel service delivery to citizens, and training of civil servants.

After that, the current Spanish e-Government strategy results from three plans: the 'Avanza Plan' (20062010) for the development of the Information Society, the 'Moderniza Plan' (2006-2008) for the modernization of the Spanish Administration, and the implementation plan of the Law on Citizens' Electronic Access to Public Services of June 2007 (the 'Law on e-Administration).

Regarding government network, a master plan for the Spain's government intranet was prepared in 2000, and the implementation of the intranet backbone began in 2002. The government intranet connects 16 ministries, 17 regional governments and a number of local entities.

In February 2006, the government officially presented the Systems of Applications and Networks for the Administrations (SARA). SARA is the IT infrastructure connecting different public authorities to exchange data and share software. At the end of 2006, the 11 autonomous communities out of 17 of Spain have already been incorporated into the SARA network.

\section{National Portal}

In September 2001, the citizen portal 'Administracion.es' first launched to provide an online gateway to public information and services. In September 2004, launch of a new e-Government portal named 'Ciudadano.es'.

After that, the '060 Network' was launched in May 2006. It is aimed to set up a new model of public service that allows Spanish citizens to interact with the three levels of government (central, autonomic and local administrations). 
In May 2007, the government released a new version of the e-Government portal 060.es. The portal offers direct access to more than 300 electronic services of the General Administration of the State. Then, in November 2007, the e-Government portal 060 was relaunched. 565 services from all three levels of government can now be reached via the portal, in which 325 are provided by the various departments of the General State Administration, 181 by Spain's autonomous communities and 23 by local authorities. New features include interactive functions such as content evaluation and commenting facilities, but also new ways of personalizing the site.

\section{CIOs in Government}

The CIO position is not a part of e-Government Strategy or Information Society Strategy. In Spain, the Ministry of Public Administrations is responsible for steering the development and implementation of e-Government in Spain's central state administration. These tasks are carried out by the Directorate General of Administrative Modernization in the Ministry's General Secretariat for Public Administrations.

\section{Required Interface}

Legal frame work for e-Government is available in Spain such as the Law on Citizens' Electronic Access to Public Services, the Law on electronic signature, the Law on Information Society Services and Electronic Commerce.

Spanish Government offers sophisticated e-services for citizens. Most of these services are in transactional level such as e-Tender, e-Tax, e-Payment, Social Security Services, Civil Registration Services, and Labor Related Services while the website of Consular service only provides downloading functions. No information related to e-voting was found.

\section{e-Government Promotion}

The legal mechanism for e-government in Spain is under the Law on Citizens' Electronic Access to Public Services. The 'Avanza Plan', the 'Modeniza Plan' and the action plan of the Law are implemented at national and sub-national level.

Enabling mechanism of e-Government include government agencies, autonomous communities and municipalities, 'Red.es' a state-owned company and others. In which entities, the Ministry of Public Admin- istrations and the Ministry of Industry, Tourism and Trade are in charge of implementation of e-Government in Spain's central state administration. There is no eGovernment fund but an ICT budget is allocated as part of the agency's national budget.

As for assessment mechanism, Spain has the Observatory within the General Administration, the Defender of e-Government users (integrated to the Ministry of Public Administrations), the Advisory Council of eGovernment and ASTIC - the professional association of IT experts and managers of the General Administration.

\section{Trends}

The adoption of the Law on Citizens' Electronic Access to Public Services puts Spain in a privileged position in the international area because only few other countries have a similar rule. In addition, Spain has taken a very important leap in this area over the past three years. Spanish government offers for citizens not only the availability of public services online but also a high degree of accessibility.

\section{SWEDEN}

\section{General Information}

The population density is some 20 people per square $\mathrm{km}$ and about $85 \%$ of the population lives $\mathrm{km}$ urban Sweden is located in Scandinavia with an area of about 450,000 square $\mathrm{Km}$. Its population was $9,182,000$ in December 2007.

\begin{tabular}{lc}
\hline Series Name & 2007 \\
\hline $\begin{array}{l}\text { Internet subscribers (Total fixed broadband) } \\
\text { per 100 inhabitants }\end{array}$ & 34.33507919 \\
Internet subscribers (Total fixed) per & 43.12994766 \\
100 inhabitants & \\
Internet users per 100 inhabitants & 76.76319122 \\
Main (fixed) telephone lines per & 60.37973404 \\
100 inhabitants & \\
Mobile cellular telephone subscribers per & 113.7301483 \\
100 inhabitants &.. \\
Personal computers per 100 inhabitants & 9118954 \\
Population & \\
\hline
\end{tabular}

Sweden is a monarchy where the office of Head of State is held by a King or Queen. Head of State is the nation's supreme representative but has no political powers. Now, Sweden's Head of State is King Carl XVI Gustaf, who has been the Head of State since 1973. Government administration is headed by a Prime 
Minister who is chosen by the nation's legislative body. The country is divided into 21 counties and has 290 municipalities.

In 2007, there are 76.76 Internet users per 100 inhabitants. Among those internet users, almost 50\% users are using broadband network to access Internet. The Swedish government has established electronic services to serve its citizens and enterprises. In 2007, $47.2 \%$ of individuals used the internet to obtain information from public authorities and more than $50 \%$ of enterprises returning filled forms to public authorities through Internet.

\section{e-Government Status by Indicators}

\section{Management Optimization}

In 1998, Swedish Government presented a bill to modernize its public administration and management. In 2000, an Information Society for All Bill was enacted. The objectives of this bill is to strengthen Sweden as an Information Society and use Information Communication Technology in order to increase such as, regional development, democracy, quality of life and efficient Public Administration.

Succeeding the An Information Society for All Bill, in 2005, the Swedish government revealed new ICT policy called From an IT policy for society to a policy for an Information Society. Its goal is to enable the country to regain its position as a global Information Society leader.

The newest plan is the Swedish Action Plan for a modern e-Government, which was presented on 24 January 2008. The document highlights the prioritized policy areas until 2010. The Swedish Government has an intranet service for secure communication within the country between Swedish Government Agencies called Swedish Government Secure Intranet (SGSI) and Government e-Link to exchange of information among Government Agencies and between these and their customers securely.

\section{National Portal}

The Swedish Government portal is www.regeringen. se with a simple design that allows users to control its interface. Moreover this portal also provides facilities for disabled persons to access the portal and obtain information. In this portal, the government provides information about the role and responsibility of each agency and allows users to access and request government documents, so that this portal could serve any business and institution.

\section{CIOs in Government}

The Minister for Local Government and Financial Markets holds political responsibility for eGovernment. In addition, Swedish Government appointed Director-General of the Swedish Administrative Development Agency (Verva) as Head of eGovernment. However, there is no specific CIO office and law to define CIO role or mandate.

\section{Required Interface}

There are several legislations enacted by Swedish Government to regulate digital transactions, such as Electronic Commerce Act, Electronic Communication Act and Electronic Signature Act. The Swedish Government has established electronic services for its citizens and businesses, some of which allow users to have transactions such as e-Payment system, e-Tax system, and Social security services, while others provide two-way interaction such as e-Tender System and civil registration services

There is no significant e-services portal, however electronic services are provided by responsible agencies. Swedish citizen should register to get their personal ID in order to be able to use electronic services.

\section{e-Government Promotion}

Since March 2008, Swedish e-Government portal (www.sverige.se) has closed down. Therefore, there is no specific portal for e-Government. Sweden has laws, plans, policies and strategies in e-government at the national level. Swedish government collaborates with private and academic institutions both locally and internationally in order to promote e-government and to establish Information Society in Sweden.

\section{Trends}

In 2008 the government launched the Swedish Action Plan for a modern e-Government. The goal is for Swedish public administration to be the simplest in the world by 2010 .

Government appointed IT Policy Strategy Group consisting of IT and policy experts from the public and private sector. It has been tasked of advising the government on how to achieve the goal of Information Society for All in Sweden. However, from year 2009, Sweden will not have a specific agency to promote e-government services. The reason is because Ver- 
va, The Swedish Administrative Development Agency, will discontinue as stated in Government's budget proposal for 2009 .

\section{TAIWAN}

\section{General Information}

Taiwan is an island in East Asia. "Taiwan" is also commonly used to refer to the territories governed by the Republic of China (ROC). In practice, almost all government power is exercised at the national and local (city/county) levels. The dominion is $36,000.18$ square $\mathrm{km}$., while the nation had a population of $23,007,737$ in 2008. The GDP per capital is USD \$16,030 in 2006.

Since 1980, Taiwan has been dedicated to the development of ICT industry. The most famous achievement is Hsin-Zhu Science Park which creates a cluster effect in terms of semiconductor, computer, and communication industry. With the innovative ODM, OEM and EMS model, many leading edge IT companies like TSMC, Foxconn, Acer, QUNTA have been established in Taiwan.

In Taiwan, $44 \%$ are Internet users who get online frequently. Among those Internet users, most of them are using broadband network to access Internet. The cellular phone penetration rate is more than $100 \%$ in 2008, and among those users, $36.4 \%$ are using $3 \mathrm{G}$ network. Generally speaking, Taiwan has a relative high readiness in terms of ICT, and most people are aware of using those equipments and facilities.

\begin{tabular}{lc}
\hline Series Name & 2007 \\
\hline $\begin{array}{l}\text { Internet subscribers (Total fixed broadband) } \\
\text { per 100 inhabitants }\end{array}$ & 20.93140602 \\
Internet subscribers (Total fixed) per 100 & 26.08517456 \\
inhabitants & \\
Internet users per 100 inhabitants & 64.44880676 \\
Main (fixed) telephone lines per 100 & 62.49834061 \\
inhabitants & \\
Mobile cellular telephone subscribers per & 106.1133575 \\
100 inhabitants &.. \\
Personal computers per 100 inhabitants & 22901896 \\
Population & \\
\hline
\end{tabular}

\section{e-Government Status by Indicators}

\section{Management Optimization}

Since 1998, Taiwan Government (TWG) has started to implement an e-Government strategy. From 19982000 , the main tasks of e-Government were to estab- lish the related infrastructure like network, legal framework and security. In this stage, the Government Services Network was built in order to enable all government agencies to connect to each other. From 20012004, TWG focused on the development of individual applications in different bureaus or departments. For example, many administrative e-Applications such as documentary, human resource and budgetary were set up in this stage. From 2003-2007, TWG started to integrated the different systems into one platform, as well as building the co-location services which provide more than 40 access line for users. Again, the remote backup and disaster recovery system was built in this stage. Presently, the "Excellent Network Government" was launched by TWG in order to promote the e-government services and user's satisfaction with it as well.

\section{National Portal}

The portal of TWG (www.gov.tw) is an integrated platform for not only citizens but also enterprises and foreigners. It provides many kinds of information and services, and most of them can be accessed within the web site. The portal has even been thought of as top ranking many times by Brown University. To sum up, the portal of TWG is beyond average on all items, however, some advanced function should be added in the future, sharing tagging and a blog for example.

\section{CIOs in Government}

From 2005, a CIO was appointed only at the national and ministry level in order to employ human resource effectively. Science and Technology Advisory Group (STAG) is as CIO in national level which is the staff of Executive Yuan to deal with the ICT related issues and policy.

A number of CIO development programs are held in Taiwan. As mentioned, Taiwan has a strong base in terms of ICT, so that more than 30 universities that provide CIO or IT related course, and CIO related organizations are also available both in academic and private.

\section{Required Interface}

Basic legal framework for the e-Commerce is available such as individual information protection act and eSignature act. Based on the development of last decade, TWG has established many sophisticated applications, and some of them allow users to have the transaction- 
al function such as e-Tender system, e-Tax system, ePayment system, Social security services and civil registration services, while other provide the downloading function like consular services and labor related services.

\section{e-Government Promotion}

As for the e-Government promotion, the main legal mechanism is under the national project called "excellent network government". It mentioned clearly that the responsible departments for different tasks or missions. However, Research, Development and Evaluation Commission of Executive Yuan is the policy maker of e-government. They also held many related activities like seminar and conference to promote the eGovernment policy. A journal called RDEC Journal is published once two months. They are also the oversight group of e-Government.

\section{Trends}

Taiwan has been committed to the development of e-Government for more than ten years. From infrastructure establishment to innovative services, TWG put a lot of effort to improve not only the internal effective and efficiency but the dynamic e-Services toward external customers. With a clear and step by step evolution on e-Government, the e-Government mechanism is getting progress in terms of supply side (government side). However, as for the demand side, even though most of people have ever heard what the e-Government is, but only few have ever actually used the government website or services. From now on, the main mission of TWG is to promote the citizens' usage of e-Services and their satisfaction toward those e-Services as well. Using one stop services portal and providing an innovative feedback system allow citizen to get involvement in online government. The final goal is to achieve the e-democracy via e-participation.

\section{THAILAND}

\section{General Information}

The Kingdom of Thailand, lies in the heart of Southeast Asia. Thailand is a constitutional monarchy with the King Bhumibol Adulyadej. The head of government is the Prime Minister. Thailand is divided into seventy-six provinces. The Ministry of the Interior ap- points governors for all but one province - the greater Bangkok metropolitan area.

Thailand has a surface area of 513,115 square kilometers and the population with approximately $65,493,298$ million people. The GDP in 2007 is USD $\$ 245.351$ billions. In $2008,20.5 \%$ of the population in Thailand has Internet access, with about 600,000 broadband subscribers.

\begin{tabular}{lc}
\hline Series Name & 2007 \\
\hline Internet subscribers (Total fixed broadband) & 1.429160476 \\
per 100 inhabitants &.. \\
Internet subscribers (Total fixed) per 100 & \\
inhabitants & 21.0006752 \\
Internet users per 100 inhabitants & 10.99506378 \\
Main (fixed) telephone lines per 100 & \\
inhabitants & 80.42250061 \\
Mobile cellular telephone subscribers & \\
per 100 inhabitants &.. \\
Personal computers per 100 inhabitants & 63883660 \\
Population & \\
\hline
\end{tabular}

\section{e-Government Status by Indicators}

\section{Management Optimization}

Thailand's IT policy framework for the years 20012010 , or IT 2010, has been approved by the Government in March 2002. IT2010 put forward the vision for the country to properly exploit IT to achieve economic prosperity and social equity. To achieve the goals, IT 2010 identified five main flagships: e-Government, e-Education, e-Society, e-Commerce, and e-Industry.

In September 2002, the ICT Master Plan from 20022006 had been approved by the Cabinet. This national master plan established a framework for e-Government in Thailand. Then in March 2003, the Cabinet announced the Thailand e-Government plan.

Government Information Network (GIN) integrates the information network of all government agencies to the Ministerial Operation Centre (MOC) and Departmental Operation Centre (DOC), and Prime Minister's Operation Centre (PMOC). With GIN, government's data and information can be managed more effectively with high security.

\section{National Portal}

The portal of Thailand government www.thaigov.go. th provides basic information about the government for citizens. The navigation and interface are good, while the interactivities with users and technical issues are poor. The portal is available in Thai and English. However, English version is simpler than Thai version. 


\section{CIOs in Government}

The position of CIO in the bureaucracy is mentioned in ICT Master Plan 2002-2006. CIOs are appointed at all level except town/city level. Government CIO office is established at national level.

There are several organizations for $\mathrm{CIO}$, such as CIOs Association of Thailand (CIO and IT persons from both government and private sectors), International Academy of CIO in Thailand. National Electronics and Computers Technology Center (NECTEC) study about CIOs. NECTEC also coordinate with other organizations to hold CIO related activities like seminars, conferences and workshops.

\section{Required Interface}

In term of cyber security, Thailand has the Electronic Transaction Law (Amended in February 2008), Computer Crime Law (enacted since 2007), Electronics Funds Transfers Law (enacted since 2008). With regards to the e-Tender system, Thailand has a plan but no website was found. E-tax and e-payment system are provided at transactional level. No plans are available in term of e-Voting, Social Security Services. Other services including Civil Registration Services, Consular Services, and Labor Related Services are offer with downloading functions.

\section{e-Government Promotion}

E-Government Promotion \& Development Bureau (Under Ministry of Information and Communication Technology) is in charge of e-government promotion in Thailand. Enabling mechanism includes all ministries, some local governments, and some state-owned companies in telecommunication. There are collaborations with international partnerships such as World Bank, Boston Consulting Group, etc.

Funds for e-Government consist of ICT budget allocation as part of the agency's national budget and the official development assistance from outside.

National Information Technology Committee, National Electronics and Computer Technology Center (NECTEC), IT Operations Support Office are government entities involved in assessment mechanism.

\section{Trends}

Thailand gets high points in Management Optimization, CIO in government and e-Government Promotion but quite low points in Portal and Required Inter- faces. They have good policies, strategies but they have not achieved the targeted time-line. As for e-services, Thailand has many projects, but most are small in scale and have not yet been completed.

\section{UNITED KINGDOM}

\section{General Information}

The United Kingdom has London as the capital city. The total area is $244,820 \mathrm{~km}^{2}$ and the population is $60,975,000$ people (2007), as number 22nd in the world.

The UK is a developed country, with the fifth (nominal GDP is USD 2.23 trillion in 2007) largest economy in the world. It was the world's first industrialized country and the world's foremost power during the 19th and early 20th centuries. The currency is Pound sterling and the national language is English.

The United Kingdom is a constitutional monarchy with a King or a Queen as the head of state. The monarch of the UK also serves as head of state of fifteen other Commonwealth countries, putting the UK in a personal union with those other states.

Executive power is performed by the Government, which is headed by the Prime Minister and his Cabinet.

The UK has the equal mix of buried cables, microwave radio relay, and fiber-optic systems. According to the data from ITU, currently there are 71,992,500 mobile phones (68.1\% population) and $33,681,100$ fixed lines $(55.43 \%$ population). For Internet, there are $17,507,000$ internet subscribers $(28.81 \%$ of population) where the Internet users are 40,200,000 users (66.15\% of population). The connection to broadband has been accessed by 15,528,700 broadband subscribers (25.55\% of population).

\begin{tabular}{lc}
\hline Series Name & 2007 \\
\hline $\begin{array}{l}\text { Internet subscribers (Total fixed broadband) } \\
\text { per 100 inhabitants }\end{array}$ & 25.55367851 \\
Internet subscribers (Total fixed) per 100 & 28.80930328 \\
inhabitants & \\
Internet users per 100 inhabitants & 66.15221405 \\
Main (fixed) telephone lines per 100 & 55.42650223 \\
inhabitants & \\
Mobile cellular telephone subscribers per & 118.4693146 \\
100 inhabitants &.. \\
Personal computers per 100 inhabitants & 60768944 \\
Population & \\
\hline
\end{tabular}




\section{e-Government Status by Indicators}

\section{Management Optimization}

The UK has a long history of its e-Government development. The embryo was started back in 1957. In 1957, the UK Government established the Technical Support Unit (TSU) to evaluate and advise on computers, employing engineers from the telecommunications service. Since then, the efforts to e-Government have been improving and in 1997, a new Labor Government was appointed with one of its main priorities of 'Electronic Government', harnessing new technology to provide simpler, efficient and responsive services to citizens and businesses.

The UK Government published 'Transformational Government - Enabled by Technology' in November 2005. The strategy set out how effective use of technology to deliver services designed around the needs of citizens and businesses can make a real difference to people's lives. This implementation plan describes the actions taken since publication and the tasks to be completed.

\section{National Portal}

The official website www.direct.gov.uk. Directgov is the Government's flagship digital service, delivered through the Directgov website and digital television. Directgov offers the widest range of government information and services online.

Users can browse by audience groups such as 'Disabled people and carers' and 'Parents', or by topics including 'Employment', 'Learning' and 'Motoring and transport'. Alternatively, the visitor can access definitive government directories or use the search engine. Citizens can use www.direct.gov.uk for everything from renewing their driving license, car tax or passport to finding out about local schools, child minders and recycling. Book a driving test, tax your car, renew your passport, search the topics about child safety, parental leave, special educational needs and lots more. The site contains extensive content for motorists, parents, disabled people and careers together with broader information for other clearly identified customer groups.

As well as government departments, the site links through to relevant third parties, which can offer additional trusted advice and support.

\section{CIOs in Government}

The Prime Minister has set the CIO Council members and their staff the mission of "ensuring that IT supports the business transformation of Government itself so that we can provide better, more efficient, public services."

The Government Chief Information Officer (CIO) Council brings together CIOs from across all parts of the public sector to address common issues. The Government CIO leads the CIO Council, which was set up in early 2005, that is composed of 30 Chief Information Officers (CIOs) drawn from central government, local authorities and other public agencies such as the police and the National Health Service. The CIO Council meets three full day a year and is in charge of working with the e-Government Unit to produce a new IT strategy for Government for the period beyond 2005. It is also aimed at promoting the role of CIOs in the public sector and at increasing the success rate of Government IT projects.

The Government IT Profession brings together all IT professionals working across the UK public sector: UK government departments and agencies, local government, the emergency services and specialist deliverers such as the health sector. It includes everyone from new entrants through to the members of the Chief Information Officer Council.

\section{Required Interface}

An E-Commerce Law and Cyberlaw have been adopted. The UK also established applications, such as e-Tender, e-Tax, E-Tax services, E-Payment services, Civil registration, Consular services, Labor services, etc.

\section{e-Government Promotion}

The government publishes various guidelines and reports aimed to promote e-Government development in the country: Guidelines for UK government websites, UK online annual report, Quality Framework for UK government website design, e-Government Metadata Standard Version 3.0, e-Government Interoperability Framework, a policy framework for accessing e-government services, Open Source Software Policy Version 2.0, Electronic service delivery reports, etc.

There is an annual conference organized by the Government IT Profession Conference. As an integral part of its wider transformation of public services, the government has launched an awareness campaign for its own Supersite - Directgov (www.direct.gov.uk). Al- 
so, the e-Government mostly is funded by government, vendors and sponsors

For assessment mechanism, there is:

- Reliable Project Delivery program as a key element of the Transformational Government Enabled by Technology' Strategy and has been set up to develop measures to increase the success rate of the government's major IT related programs and projects.

- The NAO (National Audit Office) is an independent body in charge of scrutinising public spending on behalf of Parliament. It audits the accounts of all government departments and agencies as well as a wide range of other public bodies, and reports to Parliament on the economy, efficiency and effectiveness with which government bodies use public money to perform their duties and provide services.

\section{Trends}

The UK is very mature in developing its eGovernment. The Government is committed to delivering public services whose objectives are to fulfill the needs of their users and achieve maximum value for money for the taxpayer. Based on the annual report in 2007, the 2005 Transformational Government strategy and the Service Transformation Agreement published alongside the 2007 Comprehensive Spending Review, set out part of the Government's strategy for achieving this.

At the present time there are 50,000 government IT professionals dedicated to this e-Government activities.

In 2006-2007, the Government moved forward with plans to rationalize the main public-facing sites for service delivery to just three (Directgov, Business Link and NHSChoices). Information and services are being converged towards these sites from other government websites.

\section{UNITED STATES}

\section{General Information}

The United States is composed of fifty states with diverse ethnic and multicultural nationalities. In late 19 th century, many major technological innovations were invented by scientific researchers, which later became important technologies in our daily lives. The major language is English, yet because its diversity, government provides documentations and information in many languages to satisfy citizens' needs.

United States has a land area of around 9, 826,630 square kilometers; it has a population of about $305,345,603$ as of October 2008. United States has an estimated 223 million Internet users. The number of Internet users has been increasing drastically over the last few years. The history of United State's development of E-Government services has been long and stable compare to other countries. In addition to current services, the country is still seeking for more advanced services and technologies to provide superior services to its citizens.

\begin{tabular}{lc}
\hline Series Name & 2007 \\
\hline $\begin{array}{l}\text { Internet subscribers (Total fixed broadband) } \\
\text { per 100 inhabitants }\end{array}$ & 21.45544815 \\
$\begin{array}{l}\text { Internet subscribers (Total fixed) per 100 } \\
\text { inhabitants }\end{array}$ & 23.77853394 \\
Internet users per 100 inhabitants & 71.93627167 \\
Main (fixed) telephone lines per 100 & 53.3539505 \\
inhabitants & \\
Mobile cellular telephone subscribers per & 83.51003265 \\
100 inhabitants &.. \\
Personal computers per 100 inhabitants & 305826240 \\
Population & \\
\hline
\end{tabular}

\section{e-Government Status by Indicators}

\section{Management Optimization}

E-Government services in United States began in 1998 when the government established the Government Paperwork Elimination Act by President Clinton in 1997. Since then, United States has started developing different services that would assist the government to eliminate the use of paper. By 2000, the government deployed the top 500 forms used by citizens to the internet so that it could be easily accessed by citizens. The Memorandum on E-Government was established and mandated local governments to build secured electronic service infrastructures. Currently, the government is entering a new phase of implementing Web 2.0, which is beyond the concept of e-Government.

\section{National Portal}

United State's portal site provides a wide range of services, including services for citizens, businesses and nonprofit organizations, government employees and visitors to the United States. From the portal website, citizens are able to collect almost all information and 
documents that they might need; although, the site is limited to Spanish and English, yet mostly used documents and general information are translated into more than 80 languages. However, some other functions could be added in the future; email accounts for users, audio for text of the site, and color change in the background.

\section{CIOs in Government}

In 1996, the country passed the Clinger-Cohen Act which says that each state and departments should have a CIO to monitor, plan, and manage technology including software and hardware. By having the position of $\mathrm{CIO}$, states and departments have better efficiencies in controlling software licenses and systems and effective hardware tracking system. In addition, there are many CIO certification programs, seminars, organizations and universities in the United States. CIO related programs and IT related courses are available in government agencies, private sectors, and universities.

\section{Required Interface}

The e-Commerce policy was established in 1997 to prevent money laundering, protecting customers' privacies, monitoring the capability of vendors, alerting customers when browsing to an affiliate or third-party web site. The United States government is currently providing services including e-Tender system, e-Tax, e-Payment, social security services, civil registration services, consular services and labor related services. E-tender system started in 1999 in Georgia State and has been expanded to more states. In 2007, e-tax became free of charge and more than 73 million tax returns were filed through this service. Under The Federal Voting Assistance Program, e-voting system allows citizens to vote through the site and this service is available for citizens domestically and internationally. Lastly, in 2007, e-passport became available for citizens.

\section{e-Government Promotion}

The promotion of e-government services is managed by the Chief Information Officers Council in the executive branch. The members of this council includes the Deputy Director of Management of the office of Management and Budget, Administrator of the Office of Electronic Government, Administrator of the Office of Information and Regulatory Affairs, CIO of each agency, CIO of CIA, CIO of each military department (Army, Navy, Air Force), and other officers or employee of the United States. E-government services is controlled and managed by the Office of Electronic Government and Technology.

\section{Trends}

The United States has a well developed system for eGovernment services, including policies, acts, and designated departments that monitor, plan, and manage for over ten years. The United States started by providing basic documentation services to citizens to allowing citizens to have interactive activities through the website. The United States has invested and spent much time in developing new services and taken advantage of the fast growing technology to offer citizens with easier and faster access to the government. Currently, the United States is still seeking for better and more advanced services for its citizens. The country is concentrating on HSPD-12 to enhance security, reduce identify fraud, and protect personal privacy, e-Authentication to provide Federal agencies in implementing electronic identify verification for users of online government services, The Federal Public Key Infrastructure (PKI), a security technique that could protect transmitted data and ensure confidentiality.

Since the country has a very well organized system for e-Government services, from now on, the country would concentrate on security and privacy issues. The goal is offer citizens with a convenient, user friendly, and secured electronic government system.

\section{VIETNAM}

\section{General Information}

The population of Vietnam was estimated to be 86 million in 2008. Some $20 \%$ of the population (i.e. approximately 17 million) use Internet. Vietnam has a very centralized government where most of the government services are provided by the national government. While the government is still highly centralized, there is movement towards a more decentralization.

\section{e-Government Status by Indicators}

\section{Management Optimization}

Vietnam scored poorly (only 8 out of a possible 15) in this area as it is still in the development stage. It is doing quite well in building its infrastructures but there was no official document about e-government strategy. 


\begin{tabular}{lc}
\hline Series Name & 2007 \\
\hline $\begin{array}{l}\text { Internet subscribers (Total fixed broadband) } \\
\text { per 100 inhabitants }\end{array}$ & 1.481096506 \\
Internet subscribers (Total fixed) per & 5.997802734 \\
100 inhabitants & \\
Internet users per 100 inhabitants & 20.45431709 \\
Main (fixed) telephone lines per 100 & 32.65145874 \\
inhabitants & \\
Mobile cellular telephone subscribers per & 27.15897369 \\
100 inhabitants & \\
Personal computers per 100 inhabitants &.. \\
Population & 87375200 \\
\hline
\end{tabular}

\section{National Portal}

The Vietnamese portal at www.chinhphu.vn had almost scores in the area of navigation and interactivity. Vietnam Online, the cooperated program between Vietnamese government portal and Vietnam Television Corporation, has been broadcasted at http://vno.chinhphu.vn/vno/ for around 1 year. This program provides the update news and events in Vietnam. Despite of recent efforts, the official portal still lacked some advanced functions in the interface. Thus, Vietnam did not get point in the technical aspects for E-Portal in this survey.

\section{CIOs in Government}

There are information technology directors at all ministries but there is no legal framework for CIOs in Vietnam. In term of organization, CIO club is very active as it organized many events such as conferences or CIO awards.

\section{Required Interface}

Over the last five years Vietnam have actively implemented many projects from local to central governments to upgrade the various systems for e-government services. However, it is just at the beginning state as to provide the infrastructure. Hence, providing most of the services are still on the table.

\section{e-Government Promotion}

The Vietnamese government has initiated various projects to promote e-Government, and created funding from e-Government initiatives such as loans from some international organizations.

\section{Trends}

Vietnam has improved its ranking over the last 5 yea- rs in term of e-Government since there is significant growth in internet users as the result of the better digital infrastructure. However, as a developing country, there is a lot of work to be done before arriving at an advanced level of e-Government.

\section{THE WASEDA UNIVERISTY RESEARCH INSTITUTE OF E-GOVERNMENT}

Established in year 2002; a year after Japan launched it's 'e-Japan Strategy' aiming to become the most advanced IT nation in the world. The Institute's objective was to contribute with solutions to the various problems and issues arising with the implementation of egovernment. Our organization has also engaged in the formulation of policy recommendations to improve existing e-Government both at the local and national level. In order to carry out these tasks, the Institute is part of a research network which includes academic institutions worldwide in Asia, Europe and America, as well as governmental agencies in the Asian region.

\section{E-Government Rankings Project}

A project carried out by the Institute since year 2004. The e-Government ranking measures the development of e-government in selected countries worldwide, being the only e-government assessment from an Asian research institution.

The research team is headed by Professor Doctor Toshio Obi, Director of the Institute, and formed by researchers from many countries with different academic backgrounds, both from the private and public sector. As a result, the e-Government rankings integrates different points of view, which is the key of its uniqueness.

Each country was evaluated twice by different researchers to minimize the bias. At the same time, preliminary outcomes of the ranking were discussed with experts in e-government from international organizations such as the International Telecommunication Union (ITU), the World Bank, the Organization for Economic Cooperation and Development (OECD), the Asia Pacific Economic Cooperation (APEC). These outcomes were also discussed in international conferences organized by the Institute.

The rankings also contains a section about the trends for each of the main six fields evaluated. Finally, as this is the fifth edition of the ranking, there is a special dedicated to the evolution of e-Government over the last five years. 